\title{
ESTUDIO DE LA PRODUCCIÓN Y COMERCIALIZACIÓN DE LA CERÁMICA BAJOMEDIEVAL ENTRE LOS REINOS DE ARAGÓN Y VALENCIA
}

\author{
Concepción Villanueva Morte ${ }^{1}$ \\ UNIVERSIDAD DE ZARAGOZA
}

\begin{abstract}
Resumen: En este trabajo se presenta un análisis sobre el desarrollo que la actividad alfarera manifestó en el contexto socio-económico bajomedieval de los dos reinos peninsulares de la Corona de Aragón. Para ello se hace un breve repaso por la producción y tradición manufacturera del barro en Valencia y Aragón, así como por los intercambios y transferencias de materiales (tanto cerámicos como de elementos de construcción) favorecidos entre ambos territorios a través del estudio de los canales, redes y ámbitos comerciales surgidos en torno al espacio fronterizo que los separa, y principalmente en la aduana aragonesa de Barracas de los Jaqueses a mediados del siglo XV, ahondando en los protagonistas que fueron sujeto de su comercialización y en las condiciones de transporte y precios de venta.
\end{abstract}

Palabras clave: actividad alfarera, producción y tradición manufacturera, Valencia y Aragón, materiales cerámicos, elementos de construcción, intercambios y transferencias, aduana, s. XV.

Abstract: In this work is presented an analysis of the development that the potter activity manifested in the context socioeconomic bajomedieval of the two peninsular Kingdom of

\footnotetext{
1. Personal investigador del Departamento de Ciencia, Tecnología y Universidad del Gobierno de Aragón contratado en prácticas en la Universidad de Zaragoza, en el área de Historia Medieval de la Facultad de Ciencias Sociales y Humanas de Teruel, donde realizo mi proyecto de Tesis Doctoral titulado «Movilidad social y relaciones económicas entre los reinos de Aragón y Valencia en el siglo $X V$ », dirigido por el Dr. Germán Navarro Espinach, profesor titular del Dpto. Historia Medieval en la Universidad de Zaragoza.
} 
the Crown of Aragon. For it is made it a brief review for the production and tradition manufacturer of the mud in Valencia and Aragon, as well as for the exchanges and transfers of materials (so much ceramic as of construction elements) favored between both territories through the study of the channels, nets and commercial environments arisen around the border space that separates them, and mainly in the aragonese customs of Barracas de los Jaqueses by the middle of the XV century, deepening in the main characters that were subject of their commercialization and in the conditions of transport and sale prices.

Keywords: potter activity, production and tradition manufacturer, Valencia and Aragon, ceramic materials, construction elements, exchanges and transfers, customs, $15^{\text {th }}$ century.

\section{INTRODUCCIÓN HISTORIOGRÁFICA}

La producción alfarera y cerámica ha ocupado y ocupa principalmente cuatro importantes bloques de actuación por parte del ser humano. La producción ha sido utilizada como vajilla de cocina y contacto con el fuego (ollas, cazuelas), como vajilla de mesa o de consumo (platos, escudillas), como elementos contenedores de líquidos (cántaros, jarras), y como materiales destinados a la construcción (tejas, ladrillos, losas, azulejos).

Los artesanos que trabajan el barro entre los siglos XIII y XV manejaron una amplia gama de recursos técnicos, de herramientas y procesos de trabajo, que permitían la fabricación masiva de una producción variada de útiles destinados en lo fundamental a cubrir necesidades domésticas y constructivas. No cabe duda de que una parte nada despreciable de esta producción estaba destinada a entrar en circuitos comerciales que rebasaban el estrecho marco de la demanda local. Es precisamente en la intersección de ambos factores, tecnología y comercio, donde se plantea la cuestión del marco general de las relaciones sociales que afectaban a la manufactura alfarera y sobre todo al grado de especialización de sus artesanos.

El papel de la alfarería en la historiografía del artesanado medieval no deja de causar extrañeza. Campo de estudio habitual de ceramólogos, historiadores del arte, etnógrafos y arqueólogos, la alfarería y sus artesanos han tendido a ser vistos desde la óptica del medievalista como un cuerpo extraño, un campo en el que sus categorías habituales para el estudio de las manufacturas, técnicas, trabajo, rentas, gremios y cofradías, carecían del potencial analítico que revisten para el estudio de otras manufacturas, en especial las relacionadas con los textiles.

En la aproximación bibliográfica que nos ofrece el Repertorio de Medievalismo Hispánico, magnífica base de datos creada por la Institución Milà y Fontanals del Consejo Superior de Investigaciones Científicas de Barcelona ${ }^{2}$, donde se re-

2. Tal repertorio se puede consultar en la dirección www.imf.csic.es/ppal.htm. 
coge la labor científica de los estudiosos españoles y portugueses y de los investigadores hispanistas y lusistas sobre temas hispánico-medievales (400-1525), aparecen si buscamos por «materia» más de 1.026 referencias y más de 385 por «título» sobre trabajos relacionados con la cerámica. Esta gran magnitud de entradas nos da idea de la importancia que este tema ha venido ejerciendo en la historiografía tradicional.

En el caso de la manufactura cerámica, hemos de reconocer que existen algunos trabajos pioneros que ya se han convertido en referentes a seguir en el resto de lugares, al tratar este sector artesanal de forma monográfica o en el marco de estudios de historia industrial más amplios. Hay trabajos aproximativos como los de Ottone d'Assia ${ }^{3}$ (1971), José Luis Corral ${ }^{4}$ (1980 y 1986), Pedro López Elum $^{5}$ (1984 y 1986), F. Amigues ${ }^{6}(1986,1987$ y 1992), J. Coll, J. Martí y J. Pascual $^{7}$ (1988). Y noticias indirectas a trabajos sobre hallazgos de cerámica medieval como pueden ser los de A. Bazzana ${ }^{8}$ (1978), J. V. Lerma9 y otros (1986) y Pedro López Elum ${ }^{10}$ (1987). De la misma forma, contamos con investigaciones bastante antiguas centradas en los estudios de cerámica bajomedieval española, esencialmente dentro de la zona catalano-aragonesa, como las de Guillermo J. de

3. d'ASSIA, O., «A proposito della ceramica nel periodo delle migrazioni nell'Europa centrale e meridionale» en Atti della XVIII settimana di Studi: artigianato e tecnica nella società dell'altomedioevo occidentale (Spoleto 2-8 aprile 1970), Spoleto 1971, vol. II, pp. 749-764 (Discussione sulla lezione pp. 779-782).

4. El tema del debate historiográfico sobre la cerámica aragonesa: CorRal LAFUENTE, J. L., «Problemática y metodología para el estudio de la cerámica medieval aragonesa» en Actas de las II Jornadas sobre el Estado Actual de los Estudios sobre Aragón (Huesca, 1979), Zaragoza, 1980, vol. I, pp. 203-206; e Idem, «Bases para el estudio de la cerámica medieval aragonesa (siglos X-XV) en II Coloquio Internacional de Cerámica Medieval en el Mediterráneo Occidental (Toledo, 1981), Toledo, 1986, pp. 39-42.

5. López Elum, P., Los orígenes de la cerámica de Manises y Paterna (1285-1335), Valencia, 1984; y «Origen y evolución de dos grandes centros cerámicos medievales: Manises y Paterna» en La ceramica medievale nel Mediterraneo Occidentale, Florencia, 1986, pp. 153-181.

6. Amigues, F., «Premières approches de la cèramique commune des atéliers de Paterna (Valencia)» en L'obra aspra, XIV-Xve, Mélanges Casa Velázquez, tomo XXII, 1986, pp. 27-64; «La cerámique domestique des ateliers mudèjars de Paterna (Valencia)» en L'obra aspra, XIV-Xve, Mélanges Casa Velázquez, tomo XXIII, 1987, pp. 151-172; y «Potiers mudéjares et chrétiens de la región de Valence: de la convivialité à l'antagonisme» en Archéologie Islamique, 3 (1992), pp. 129-167.

7. Coll, J., Martí, J., y Pascual, J., Cerámica y cambio cultural. El tránsito de la Valencia islámica a la cristiana, Valencia, 1988.

8. BazzanA, A., «Céramiques communes mediévales de la region valencienne» en Colloques Internacional C.N.R.S.: 'La Céramique médiévale en Méditerranée Occidentale, X-XV ss.', Vallbonne, 1978, pp. 321-334.

9. LeRma, J. V. et alii, «Sistematización de la loza gótico-mudéjar de Paterna/Manises» en La cerámica medievale nel Mediterraneo Occidentale, Florencia, 1986, pp. 183-203.

10. López Elum, P., «La conquista cirstiana de Mallorca y Valencia y su repercusión en el ámbito de la cerámica» en Actas de las V Jornades d'Estudis Històrics Locals: 'Les Illes Orientals d'Al-Andalus', Mallorca, 1987, pp. 239-245. 
Osma $^{11}$ (1908 y 1911), J. Sanchis Sivera ${ }^{12}$ (1926), A. Sánchez Gozalbo ${ }^{13}$ (1927), F. Almela y Vives ${ }^{14}$ (1933), M. González Martí15 (1933 y 1944), Frothingham ${ }^{16}$ (1951), Ainud de Lasarte ${ }^{17}$ (1952), M. Olivar Daydí18 (1952) y Llubiá Munné19 (1967); aunque no faltaron los trabajos dedicados a la cerámica elaborada en los territorios islámicos peninsulares, como los de Gómez Moreno ${ }^{20}$ (1924), Torres Balbás $^{21}$ (1934 y 1939), Casamar ${ }^{22}$ (1959), Camps Cazorla ${ }^{23}$ (1962), Pavón Maldonado $^{24}$ (1969) y $\operatorname{Duda}^{25}$ (1970).

En un primer acercamiento historiográfico, es evidente que la desproporción entre los trabajos dedicados al artesanado cerámico y los dedicados a sus productos, no admite por el momento comparación posible. A su vez, podemos observar cómo la evolución de estos estudios corre paralela al desarrollo de la concepción misma de la Arqueología medieval, de manera que, como el resto de los ámbitos de estudio que competen a esta disciplina, la cerámica comenzará a abordarse desde una perspectiva más globalizada.

Aunque si nos interesamos en un estado de la cuestión más actualizado, es decir, mirando desde la década de los años 1990 en adelante, la bibliografía generada ha resultado ser muy heterogénea en cuanto a sus contenidos y objetivos,

11. de Osma, G. J., Los maestros alfareros de Manises, Paterna y Valencia. Contratos y ordenanzas de los siglos $X I V, X V$ y XVI, Textos y documentos valencianos $\mathrm{n}^{\circ}$ II, Madrid, 1908; y del mismo autor, Adiciones a los textos $y$ documentos valencianos $\mathrm{n}^{\circ}$ II, Madrid, 1911.

12. SANChis SiverA, J., «La cerámica valenciana. Notas para su historia medieval» en Boletín de la Real Academia de la Historia, t. LXXXVIII, 1926, pp. 638-661.

13. SÁnchez Gozalbo, A., «Alfares en Morella» en Boletín de la Sociedad Castellonense de Cultura, t. VIII, 1927, pp. 299-302.

14. Almela y Vives, F., «Vocabulario de la cerámica de Manises» en Boletín de la Sociedad Castellonense de Cultura, XIV (1933), pp. 371-384 y 397-425.

15. GonzÁlez Martí, M., Cerámica española, Madrid, 1933; y Cerámica del Levante Español. Siglos medievales, I, Barcelona, 1944.

16. Frothingham, A. W., Lustreware of Spain, Nueva York, 1951.

17. Ainud de Lasarte, J., Cerámica y vidrio, Colección Ars Hispaniae, vol. 10, Madrid, 1952.

18. Olivar Daydí, M., La cerámica trecentista de los países de la Corona de Aragón, Barcelona, 1952.

19. Llubiá Munné, Ll. M, Cerámica medieval española, Barcelona, 1967.

20. Gómez Moreno, M., Cerámica medieval española, Barcelona, 1924.

21. Torres Balbás, L., «Cerámica doméstica de la Alhambra» en Al-Andalus, II (1934), pp. 387-388; y «De cerámica hispano-musulmana» en Al-Andalus, IV (1939), pp. 412-432.

22. CASAmar, M., «Notas sobre cerámica del ajuar nazarí» en Al-Andalus, XXIV (1959), pp. 189-199.

23. Camps Cazorla, E., «Cerámica musulmana de Málaga» en Adquisiciones del Museo Arqueológico Nacional (1960-1965), Madrid, 1962, pp. 154-161.

24. Pavón Maldonado, B., «Notas sobre cerámica hispanomusulmana» en Al-Andalus, XXXII (1969), pp. 415-437.

25. DudA, D., Spanische-Islamische keramik aus Almería von 12. bis 15. Jahrundert, Heidelberg, 1970. 
aunque algunas de estas aportaciones son, sin duda, esenciales para obtener una visión general sobre el tema que nos ocupa. Asimismo, nos daremos cuenta de que el estudio de la cerámica durante esta última década implica a profesores e investigadores universitarios, pero también a arqueólogos, etnógrafos, conservadores de museos, restauradores, etc., y que su investigación ha ido adquiriendo la suficiente profundidad como para ocupar un espacio, incluso desde una perspectiva altamente analítica, en los debates abiertos dentro de la historiografía que se ha ocupado de la historia del comercio bajomedieval. Además, por lo general, todas estas obras cuentan con extensos apéndices bibliográficos que nos facilitan el conocimiento de un amplio abanico de trabajos llevados a cabo en otros contextos peninsulare ${ }^{26} \mathrm{o}$ incluso extrapeninsulares ${ }^{27}$.

La cuestión en los países de la Corona de Aragón es, hay que reconocerlo, bastante positiva, en especial en lo que se refiere a los alfareros valencianos, mallorquines y catalanes ${ }^{28}$. Es en este ámbito donde se pueden encontrar las me-

26. Entre los diversos estudios basados en fuentes documentales están los de Roselló-Bordoy, G., «Arqueología e información textual: el utillaje en la cocina andalusí» en MARín, M., y WAINES, D., (coords.), $L a$ alimentación en las culturas islámicas, Madrid, Agencia Española de Cooperación Internacional, 1994, pp. 37-87, y El verd y el morat, Valencia, 1996; BARCELÓ CRespí, Mª ., «Los límites de la información documental escrita» en Barceló, M., y otros, Arqueología Medieval. En las afueras del «medievalismo», Barcelona, Crítica, 1988, pp. 73-87; CÓRDOBA DE LA LLAVE, R., «Alfares y producción cerámica en Córdoba durante el siglo XV» en Ifigea, II (1985), pp. 195-202, e «Innovación tecnológica y desarrollo industrial en la Península Ibérica durante la Edad Media» en Actas de las I Jornadas sobre minería y tecnología en la Edad Media peninsular (León, 26 al 29 de octubre 1995), León, 1996, pp. 317-246; Álvaro ZAMOrA, Ma . I., «La cerámica en el mudéjar turolense» en Gonzalo M. BorRÁs (Coord.), Teruel mudéjar, patrimonio de la Humanidad, Zaragoza, 1991, pp. 201-237, «Léxico de cerámica mudéjar. Estado de la cuestión» en Actas del VII Simposio Internacional de Mudejarismo, Teruel, Instituto de Estudios Turolenses, 1999, pp. 549-557; o ViNYOLES i VidAL, T., «La documentació escrita com a font de la coneixença de la ceràmica» en Roselló-Bordoy, G. (coord.), Actes de las XV Jornades d'Estudis Locals. Transferències i comerç de ceràmica a l'Europa mediterrània (segles XIV-XVIII) (Palma de Mallorca, 11-13 diciembre 1996), Palma, Institut d'Estudis Baleàrics, 1997, pp. 367-411.

27. En Marruecos, concretamente en la ciudad de Rabat, tuvó lugar el 5ème Colloque sur la Céramique Médiévale en Méditerranée Occidentale en 1991, cuyas actas fueron editadas por INSAP en 1995. En Italia, también destacó el XIV Seminario Residenziale di Studi dedicado a Fonti per la storia della civiltà tardo medievale: il territorio e la cultura materiale (San Miniato, 11-16 settembre 2000), en cuyo programa G. VANNINI presentó una ponencia sobre el tema que nos interesa titulada «Una fonte materiale socialmente trasversale: la produzione ceramica».

28. En lo que respecta a la alfarería catalana medieval, merece la pena destacar PADILLA, J. I., y ViLA, J. M., «El artesanado medieval de la cerámica...», citado, pp. 249-261. La cuestión de los artesanos del barro mallorquines ha sido abordada por M. BERNAT y J. SERRA, «Ceràmica medieval mallorquina: entre la pervivència andalusina i la tradició cristiana» en IV Congreso de Arqueología Medieval Española, t. III, Alicante, 1993, pp. 825-831 y, más recientemente, por Barceló, M., y Roselló-Bordoy, G., Terrissa, Palma de Mallorca, 1996, pp. 191-202. Sin duda, los alfareros valencianos son los que mayor atención han recabado. Tres buenos ejemplos de ello son las ya citadas obras de Osma, G. J. (1908), López Elum, P. (1984) y Amigues, F. (1992). Merece la pena destacar también las recientes aportaciones al estudio de algunas alfarerías secundarias, como la de Segorbe, objeto de atención por parte de CERVANTES, F. J., «Renta feudal y organización de la producción alfarera en Segorbe, Paterna y Benaguasil. s. XV» en Actas del VI Simposio Internacional 
jores aportaciones al conocimiento de las relaciones sociales en las que se movió la producción cerámica peninsular en los siglos XIV y XV. Aragón es, desde este punto de vista, una excepción relativa. Aproximaciones a la cuestión tampoco faltan, pero estamos lejos todavía de alcanzar un conocimiento adecuado de multitud de factores implicados en la situación social y en los procesos de trabajo en los que estaban inmiscuidos los alfareros urbanos y rurales aragoneses de época bajomedieval ${ }^{29}$. La situación, para el caso turolense, es quizá algo más alentadora a raíz de la publicación del catálogo de la exposición «...Operis terre turolii. La cerámica bajomedieval en Teruel» que tuvo lugar en el Museo de esta ciudad en junio de 2002 a cargo de Julián Ortega ${ }^{30}$.

Uno de los objetivos del II Coloquio sobre Cerámica Medieval celebrado durante este mismo año en Ceuta, fue debatir sobre el estado actual de los estudios sobre la producción, el consumo y la distribución de la cerámica medieval y moderna. Paralelamente a dicha reunión y como edición de sus actas, el profesor Malpica Cuello asegura en un libro editado por el grupo de investigación «Toponimia, historia y arqueología del reino de Granada» de la Universidad de Granada y del Museo de Ceuta, que la cerámica se convierte en un objeto de

de Mudejarismo, Teruel, 1995, pp. 381-390 y APARICI, J., «Actividad artesanal de los musulmanes segorbinos en la primera mitad del siglo XV» en Actas del VII Simposio Internacional de Mudejarismo, Teruel, 1999, pp. 27-41.

29. Hay que destacar los trabajos sobre los alfareros oscenses de Escó SAMPÉRIZ, C., «Alfares, alfareros y producción cerámica en la Huesca medieval (siglos X-Xv)» en Bolskam, 3 (1986), pp. 169-198 y ConTE CAZCARro, A., La aljama de moros de Huesca, Huesca, Instituto de Estudios Altoaragoneses, 1992. También sobre los de la zona de Daroca y Calatayud de Álvaro, Ma . I., «Las tejerías de Daroca y su arrendamiento municipal durante el siglo XV» en Aragón en la Edad Media, VIII (1989), pp. 59-70; Rodrigo, Mª L., «Los mudéjares y su fuerza de trabajo en el ámbito darocense (1423-1526)» en Actas del VI Simposio Internacional de Mudejarismo, Teruel, 1995, pp. 143-165; GARCíA MARCO, F. J., «Actividades profesionales y económicas de las comunidades mudéjares de Calatayud y Daroca a finales del siglo xv (1486-1501)» en Actas del IV Simposio Internacional de Mudejarismo, Teruel, 1992, pp. 151-166, Las comunidades mudéjares de la comarca de Calatayud en el siglo XV, Calatayud, 1993. Es difícil saber por el momento en qué medida las conclusiones del importante trabajo de Álvaro, Ma . I., «El trabajo en los alfares mudéjares aragoneses. Aportación documental acerca de su obra, controles de su producción y formas de comercialización» en Revista Zurita, 65-66 (1992), pp. 97-138, con seguridad el mejor con el que contamos para hacer frente a todas las preguntas que pesan sobre la organización social de la producción cerámica en Aragón durante el siglo XVI, es extrapolable a períodos anteriores al siglo XV. Para Teruel, ya en época moderna, véase UTRILLAS, E., «Apuntes sobre la islamización de los moriscos en la ciudad de Teruel. El caso del ollero Miguel Sebastián» en A. Pérez Lasheras (coord.), Homenaje al profesor Antonio Gargallo Moya, t. II, Studium. Revista de Humanidades, 4 (1997), pp. 367-395.

30. Ortega Ortega, J. M., «Producción artesanal, transferencias comerciales y reproducción doméstica en Teruel, durante la Baja Edad Media (ss. XIII-XV)» en '... Operis terre turolii'. La cerámica bajomedieval en Teruel, Museo de Teruel, 2002. Además de la importancia de dos trabajos suyos publicados con anterioridad: «El contexto historiográfico de la 'Cerámica de Teruel': algunas reflexiones sobre las producciones medievales» y «Cerámica y feudalismo: una aproximación a la cerámica medieval de Teruel» en Kalathos, 15 (1996), pp. 79-110 y 111-141, respectivamente. 
primera magnitud para medir las técnicas productivas y el desarrollo comercial. Considerando la unión de ambas facetas como aspecto esencial para hacer avanzar los estudios ceramológicos ${ }^{31}$.

En este contexto se enmarca el trabajo que ahora presentamos. Como ya hemos señalado, el número de estudios relativos al intercambio de cerámicas es tan amplio y diversificado, tanto geográfica como cronológicamente, que ya permiten un estudio parcial, una primera aproximación, concentrando la atención sobre determinados datos o aspectos a fin de intentar observar la dinámica interna de este proceso y las líneas tendenciales que parecen apreciarse en el mismo. Sin embargo, hemos decidido limitar nuestro análisis, ocupándonos en esencia de la cerámica que llegó a Aragón procedente del reino valenciano, y a la inversa, intentando analizar e interpretar aquellos aspectos que nos parecen aportar pistas sobre la evolución del comercio de este producto durante la Baja Edad Media. Para lo que tendremos que poner de manifiesto un estado de la cuestión que exponga los notables sondeos y principales resultados puestos en marcha sobre la industria bajomedieval alfarera y cerámica en el reino de Valencia y en el sur de Aragón, zona que principalmente nos ocupa.

Dejando a un lado el debate asociado a la polémica sobre la prioridad cronológica y preeminencia de la producción cerámica bajomedieval turolense o valenciana, proponemos a continuación un breve resumen sobre el desarrollo que esta actividad manufacturera manifestó en el contexto socio-económico de ambos reinos.

\section{LA TRADICIÓN CERÁMICA EN VALENCIA}

La tradición de la cerámica en Valencia es también una herencia de la época musulmana. Posiblemente fue la industria valenciana de más prestigio y la que más fama alcanzó fuera de nuestras fronteras. Después de la conquista, Jaime I dispensa a los alfareros de Manises y de Paterna del pago de todas las tasas con el fin de que prosigan con el ejercicio de su $\operatorname{arte}^{32}$. Situados al oeste de la ciudad y apenas separados entre sí por el cauce del río Turia, los dos centros se distinguen por una producción diferente.

31. Malpica Cuello. A., Cerámicas islámicas y cristianas a finales de la Edad Media. Influencias e intercambios, Granada, 2003. Este autor fue miembro del Comité Científico del II Coloquio Internacional sobre Cerámica Medieval que bajó el mismo título se celebró en Ceuta en noviembre de 2002. Este volumen, cuyo título hemos reseñado, puede considerarse una excelente puesta al día de los problemas más debatidos actualmente en los estudios de ceramología medieval, al tiempo que presenta nuevos avances sobre cuestiones aún abiertas en cerámica medieval, como es el caso de las trasmisiones de conocimientos tecnológicos entre las diversas áreas del Mediterráneo y sobre el origen, desarrollo y auge de la cerámica almohade y nazarí.

32. Fori Antiqui Valentiae, edición de Manuel Dualde Serrano, Valencia, 1967, rúbrica CLXIV, n. 5. 
En los siglos XIV y XV, en Paterna predominan cerámicas con decorados verdes, destacándose sobre el barniz blanco, que se obtienen a partir de un baño de plomo mezclado con estaño. Esta técnica, propia de Paterna, va a difundirse hacia otros centros, en Teruel y en Cataluña ${ }^{33}$. En Manises, por el contrario, domina la cerámica azul que encontramos en la anterior época califal y, más tarde, en Granada bajo la dominación nazarí. Exige, como la cerámica verde, dos cocciones: la primera permite cocer el molde de arcilla, mientras que la segunda lleva al artista a recubrir el objeto con un barniz de sulfuro de plomo, de bióxido de estaño y de sílice, sobre el cual se dibuja la decoración con el óxido de cobalto diluido para darle el color azul.

Tradicionalmente se ha considerado que la cerámica verde y manganeso de Paterna era la primera en el tiempo, a la que sucedía la dorada de Manises, siendo la última la azul y dorada de este último lugar, basándose para ello en unos pocos documentos, de los cuales alguno había sido mal leido o interpretado. Sin embargo, los recientes estudios de López Elum a través del análisis de fuentes archivísticas, fundamentalmente protocolos notariales del Archivo del Reino de Valencia, entre los años 1235 al 1335 -los primeros cincuenta años de los que existe constancia documental de dicha cerámica- nos ofrecen una visión del tema muy distinta de la que nos ha mostrado la bibliografía tradicional ${ }^{34}$.

En cuanto a los orígenes de la cerámica bajomedieval valenciana, han sido estudiados en profundidad ${ }^{35}$. Los investigadores que han tratado el tema, lo han podido hacer desde diversas perspectivas, tanto la que aporta la documentación escrita $^{36}$, en este caso numerosa en contraposición a los territorios islámicos, como a través del análisis de los materiales cerámicos, esencialmente desde una perspectiva decorativa o estilística ${ }^{37}$. Al respecto, los resultados obtenidos son los siguientes: en primer lugar, ha habido que aclarar el significado preciso de la nomenclatura empleada por los maestros de obras para designar sus piezas y calidades. Y así se definen términos como pictum et album, aureum, Malacha y dauratus, sinónimos todos ellos de la loza dorada. Ya en el siglo XIV, los maestros alfareros de Manises restablecen la tradición de la cerámica de reflejos

33. Sobre estos temas véase de Osma, J. G., Apuntes sobre cerámica morisca, II. Los Maestros alfareros de Manises, Paterna y Valencia. Contratos y ordenanzas de los siglos XIV, XV y XVI, Madrid, 1908.

34. López Elum, P., Los orígenes de la cerámica..., citado, 1984.

35. Destacamos el trabajo de MARTí, J., «Una manufactura a la búsqueda de paternidad. Apuntes sobre el inicio de la producción de cerámica decorada bajomedieval en el área valenciana y dentro del contexto del Mediterráneo Nordoccidental» en Albisola, XXXI (1999), pp. 195-206.

36. López Elum, P., «Origen y evolución de dos grandes centros cerámicos...», citado, pp. 153-181.

37. GonzÁlez Martí, M., Cerámica del Levante español, citado, 1944; y Amigues, F., «La cerámica góticomudéjar valenciana y las fuentes de inspiración de sus temas decorativos» en Spanish medieval ceramics in Spain and the British Isles, Tempvs Reparatum, Oxford, 1995, pp. 141-175. 
dorados, denominada «obra de Malica» u «obra de Málaga» porque fue en esta ciudad donde obtuvo su fama en la Península. La introducción de la loza dorada en este lugar debió de producirse, no como un fenómeno aislado, sino dentro de un conjunto de innovaciones técnicas, entre las que hay que mencionar el empleo del color azul -sólo o con el dorado- en la decoración de las piezas, así como el del verde-morado. Estos conocimientos serían de uso común (sobre todo los dos primeros) en su lugar de procedencia, y penetraron en Valencia a través de Manises. Luego se imitarían en Paterna. Hay que destacar el origen turolense de la cerámica verde-morada aquí producida, según los planteamientos de López Elum, que también cuestionan la versión de una repentina sustitución de la cerámica islámica por otra cristiana en el reino de Valencia tras la conquista de Jaime I.

Es evidente el predominio de artesanos mudéjares en las labores cerámicas. Prácticamente podemos hablar de monopolio. La mayoría de los contratos de compraventa conocidos los suscriben musulmanes expertos en cerámica dorada. Ello es un indicio, entre otros, de la introducción de esta técnica por correligionarios, probablemente llegados del reino de Granada o quizá de Murcia. Lo que está claro es que se trataba de un fenómeno importado.

Llama la atención el hecho de que sastres valencianos compraran loza dorada en Manises y obra aspra -nombre con el que se designaba la cerámica común, no de cerámica de lujo- en Paterna para su posterior venta y comercialización. Mercaderes de Narbona que venían a Valencia para realizar negocios de carácter textil, regresaban a su ciudad habiendo suscrito contratos de compra de piezas de cerámica. Parece ser que en sus tiempos iniciales parte de la producción de Manises y Paterna se canalizaba a través de personas relacionadas con el sector textil.

López Elum señala diversas circunstancias que favorecieron la instalación de un centro productor de loza dorada en Manises: el auge económico y comercial de Valencia, así como su excelente posición dentro de las redes comerciales de la época; facilidad para obtener materias primas esenciales como el estaño y, sobre todo, la arcilla; la permanencia en territorio valenciano de gran parte de su población musulmana anterior a la conquista; la existencia de una alfarería de origen islámico, que prosiguió tras la creación del reino de Valencia; las relaciones entre la Corona de Aragón y el reino de Granada; y el paso del señorío de Manises a la familia de los Boïl. Ello benefició a esta localidad por partida doble, ya que, por un lado, la hizo salir de una grave crisis interna que venía padeciendo desde finales del siglo XIII (junto con Paterna) bajo los Luna; y, por otra parte, las relaciones del nuevo señor, Pere Boïl, con el reino de Granada -al que fue como embajador de Jaime II entre finales de 1309 y comienzos de 1310- facilitó el contacto con la zona clave en la producción de loza dorada. Todos los indicios apuntan, pues, al origen malagueño de esta cerámica: el nombre con que se la identifica (obra 
de Màlecha), el testimonio de los cronistas árabes, que hacen de la ciudad andaluza un importante centro de fabricación de la misma. Quizá habría que pensar en el reino de Granada en su conjunto, y no tan sólo la ciudad de Málaga, como procedencia de la cerámica dorada.

También en Paterna la artesanía de la cerámica estaba en manos mudéjares en gran parte, con plena capacidad jurídica para realizar contratos acerca de su producción, y que en ocasiones aparecen ayudando a fabricantes cristianos, pero en pie de igualdad. Asimismo, eran también los mudéjares quienes vendían las piezas a los mercaderes cristianos. De hecho, la terminología de las piezas de Paterna era también de origen árabe en un principio (alcolla, alfàbia), pero desde 1317 se impone el nombre de gerra. El Llibre del Repartiment, donde consta la donación de Manises y Paterna a Artal de Luna en 1237, no puede ser utilizado como fuente para negar la existencia de una actividad alfarera en Paterna antes de la conquista, ya que en él no se registran nunca las peculiaridades económicas de las donaciones, ni las actividades de la población. Igual que sucedía en Manises, también la alfarería de Paterna, en su proceso de distribución comercial, aparece relacionada con el sector textil.

En esta etapa cronológica los objetos fabricados eran tinajas de distintos tamaños, y no se han encontrado referencias documentales a la producción cerámica verde-morada. El conocimiento de esta loza hay que situarlo en el siglo XIV dentro de los cambios sufridos entonces por la alfarería local. Los artesanos de Manises serían los introductores de la nueva técnica, que llegó a Paterna algo más tarde. En torno a 1325 uno de los requisitos que se exigía a la cerámica más elaborada en Manises -la loza dorada- era que estuviese realizada sobre fondo blanco inverniçato verniçio albo, por lo que en alguna ocasión el comprador proporcionaba la materia prima necesaria: el estaño. Esta disposición nos hace pensar que el uso de este producto estaba poco generalizado entre los artesanos ceramistas, por lo que resultaba difícil aceptar su empleo en Paterna desde la segunda mitad del siglo XIII, precisamente en la cerámica verde-morada, la menos cuidada en su barnizado total.

En definitiva, Manises y Paterna experimentaron un importante desarrollo de su industria alfarera. En un principio ambos lugares caminaron paralelamente, pero desde principios del siglo $\mathrm{XIV}^{38}$-antesala del despegue comercial de esta producción cerámica a lo largo de la centuria siguiente-, en ambos se observa una trayectoria diferente. En Manises se introdujo la técnica de la loza dorada, y

38. La producción cerámica valenciana, desestructurada tras la conquista aragonesa, como parece quedar demostrado, vuelve a reestructurarse a mediados del siglo XIV, recogiendo de un modo directo, atrayendo quizás artesanos granadinos en algunas de sus producciones, la tradición cerámica nazarí, con la que competirá y a la que finalmente y desde el punto de vista comercial terminará desbancando. 
aunque se siguió elaborando obra aspra, se afianzó en sus talleres por encima de las labores menos lujosas.

Durante las dos últimas centurias de la época medieval, Guillermo de Osma censó más de cien nombres de alfareros musulmanes y cristianos en estos dos centros, que, reagrupados con los maestros de obra, formaron un gremio distinto a principios del siglo XVI. Su producción, a la vez decorativa y utilitaria, se orientaba a la fabricación de vajillas o de revestimientos murales y de embaldosados.

Un envío de vajillas de Manises, cuyas piezas fueron realizadas por el maestro alfarero Azmet Zuleyma, permite evocar la diversidad de esta producción. Se trata de 256 piezas compradas por la compañía italiana de Francesc di Marco Datini que son expedidas a Venecia a otra gran compañía florentina, la de Zanobi Gaddi y Antonio di Ser Bartolomeo. Embaladas en grandes jarras de cerámica, las diferentes piezas se reparten entre «escudillas, platos trincheros, pequeñas escudillas, saleros o platos para especias, vasijas, platos pequeños, vasos de dos asas, los 'alfabequers', y pequeños tarros para conservar las hojas de albahaca ${ }^{39}$.

Y si la variedad de formas es grande, no menos lo es la gran riqueza de decoracion de las piezas. Las representaciones zoomórficas y antropomórficas son quizás las más representativas del arte medieval de Paterna y Manises.

La mayoría de los artesanos trabajan por encargo. Así en mayo de 1421, Alí Laxoni, maestro de «obra de terra» de Manises, realiza para la reina María, esposa de Alfonso V, 20 servidores de tierra en esmalte blanco puro, destinados a servir de presentadores de peladillas y de confitados en la mesa real. Otros, en cambio, se especializan en la fabricación de tarros de boticarios y de morteros; en la fabricación de jarras de arcilla cocida; o en la confección de los moldes de azúcar en cerámica, donde se muelen los panes de azúcar fino y sin refinar de los molinos azucareros. Los nombres de cantarers, ollers o gerrers que se emplean para denominar a los alfareros en los documentos de este tiempo son genéricos y se utilizan indistintamente, sea cual sea la clase de cerámica que fabriquen.

La producción está, por lo tanto, muy diversificada y desemboca en la creación de obras maestras realizadas por encargo de la aristocracia y de la nobleza, de las que todavía hoy sobreviven algunas piezas conservadas en los museos. La característica más definitoria de su trabajo consiste sobre todo en realizar objetos utilitarios, bellos y de calidad, y su uso se expande a medida que la vida y las artes de la mesa se vuelven más refinados.

Por último, la cerámica de Paterna y Manises alcanzó una gran difusión internacional desde Italia y Francia a Berbería y los países atlánticos. Por lo ge-

39. SpallanZani, M., «Un invio di Maioliche ispano moresche à Venezia negli anni 1401-1402» en Archeologia Medievale, t. V, 1978, pp. 529-542. 
neral, los azulejos se embalaban en sacos de esparto y las piezas de vajillas en tinajas. Hay numerosos contratos de embarque de estas piezas cerámicas, consideradas también como un objeto precioso en la época del Renacimiento, y así lo atestiguan los Médicis, Renato de Anjou o las grandes familias principescas que buscaban estas piezas. Incluso los grandes pintores (Van Eyck, Van der Goes, Girlandaio, etc.) las reproducen en sus cuadros ${ }^{40}$. Citemos a título de ejemplo que el senado de Venecia hizo una excepción en su arancel de aduanas a favor de la cerámica de Manises, puesto que las demás tenían prohibida su importación ${ }^{41}$. Y, también por su situación, Cerdeña fue una de las islas mediterráneas más transitadas comercialmente en la Baja Edad Media y, en consecuencia, más permeable a la entrada de productos cerámicos; era una escala de fundamental importancia en la denominada ruta de las islas, y por lo tanto en el trasiego marítimo mediterráneo, lo que justificaba el interés que sobre ella tuvieron las ciudades comerciales tirrénicas italianas (Pisa y Génova esencialmente), y posteriormente el reino de Aragón. Por ello no resulta extraño que las aguas sardas alberguen una riqueza arqueológica de primera índole, especialmente al Sur, donde han sido documentadas varias naves hundidas con material cerámico español ${ }^{42}$.

Pero dentro de la cerámica valenciana no sólo destacan la de estos dos epicentros, sino también la incidencia especial que tuvo la propia ciudad de Valencia, o los obradores de Cárcer y Alacuás; o la influencia de la cerámica propia de las tierras castellonenses, con las manufacturas de Alcora, Ribesalbes y Onda, con un amplio y variado repertorio de formas, estilos y motivos, al igual que la cerámica aragonesa de Teruel, Muel, Villafeliche y Rubielos ${ }^{43}$.

40. En relación a la iconografía e historia de las imágenes, queremos señalar que hay que tener en cuenta que, por ejemplo, la introducción de obras del gótico internacional en el sur de Aragón fue en buena medida debida, o bien directamente a pintores valencianos, caso de Pere Nicolau, Marçal de Sax o Gonzalo Periç, o bien a pintores aragoneses influidos o incluso formados bajo las directrices de aquellos [Consúltese. SEBAstián, S, «La pintura gótica en Teruel» en Teruel, XXXVII (1967), pp. 15-50, en concreto en las pp. 31-41].

41. García Porras, A., y Fábregas García, A., «La cerámica española en el comercio mediterráneo bajomedieval. Algunas notas documentales» en Miscelanea Medieval Murciana, pendiente de publicación. En este trabajo se precisa la evolución del comercio de importación de la cerámica bajomedieval procedente de la Península Ibérica en las distintas ciudades italianas, afrontando la cuestión desde el enfoque italiano que ofrecen los centros de recepción y redistribución de esta cerámica, en confrontación a la óptica española que se ocupa fundamentalmente de los centros productores, su cronología y las características tanto decorativas como morfológicas de las piezas.

42. Véase García Porras, A., «La cerámica española importada en Italia durante el siglo XIV. El efecto de la demanda sobre una producción cerámica en los inicios de su despegue comercial» en Archeologica Medievale, XXVII (2000), pp. 131-144.

43. Pueyo Dolader, O., La alfarería de Rubielos de Mora, Instituto de Estudios Turolenses-Ayuntamiento de Rubielos de Mora, Teruel, 2003. 
Hay que subrayar también la relevancia que tuvo el traslado de artesanos desde los dos importantes centros cerámicos valencianos, sobre todo desde Paterna, hacia el norte valenciano, puesto que consideramos que fue un fenómeno generalizado, fruto del despegue industrial de aquel centro y de las medidas promotoras de su asentamiento en los lugares receptores. Así, por ejemplo, la transferencia técnica desde el centro cerámico de Paterna a Castellón sabemos que fue importante no sólo por los seis casos que han sido identificados cuya actividad coincide en los años 1447-1484, sino también por cierta misiva del municipio castellonense al notario Nicolau Caposa, su síndico en Valencia, con fecha 13 de abril de 1457, donde se explica que varios canterers de Paterna se habían asentado en Castellón para ejercer su oficio y que desde la villa de Paterna se quería evitar su emigración imponiendo una multa a todos los que se marcharan ${ }^{44}$. Además, hacia 1391 se habían instalado en Morella varios artesanos de Paterna recibiendo unas casas y permiso para construir un horno cerámico ${ }^{45}$. Pese a ello, en Castellón no deberíamos descartar una segunda vía de influencia exterior, presumible mediante los contactos que pudieran producirse con Traiguera, centro manufacturero destacado a partir del siglo $\mathrm{XvI}^{46}$.

\section{PRODUCCIÓN ALFARERA EN ARAGÓN}

Partiendo de los principales centros de cerámica decorada aragonesa (Teruel, Muel, Calatayud, Villafeliche, Morata de Jalón, María de Huerva y Zaragoza, entre otros) se han podido estudiar sus técnicas y sistemas de trabajo, las tipologías de piezas obradas y los repertorios decorativos empleados en su ornamentación, a partir sobre todo de la consulta de numerosos archivos y del inventario y catalogación de las obras conservadas in situ, en museos y colecciones nacionales y extranjeras, o procedentes de excavación.

Las noticias sobre alfares rurales aragoneses son relativamente abundantes, cuya existencia parece quedar demostrada al menos desde finales del siglo XIII. Aunque no faltan referencias documentales anteriores, como es el caso de Cala-

44. Iradiel, P., Igual, D., Navarro, G., y Aparici, J., Oficios artesanales y comercio en Castelló..., citado, p. 76.

45. SÁnchez Gozalbo, A., «Alfares en Morella», citado, pp. 299-302.

46. Díaz Manteca, E., «Pere Jullach, el primer canterer traiguerí conegut (1380)» en Traiguera, 127 (1988), p. 11; Rosas, M., «Notes sobre la cerámica de Traiguera a propòsit d'unes peces del segle XVI» en Penyago-

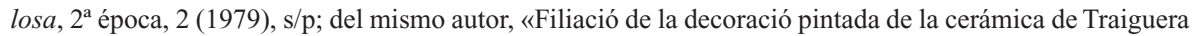
(Castellón de la Plana)» y "Anàlisi de dos fragments de ceràmica del segle XVI procedents de Traiguera (Castellón de la Plana)» en Boletín de la Sociedad Castellonense de Cultura, 68 (1992, pp. 335-346 y 567-572; Ferreres, J., y Rosas, M., «Gerres baixmedievals de l'Ermita de la Font de la Salut de Traiguera (Castellón de la Plana)» en Boletín del Centro de Estudios del Maestrazgo, 41-42 (1993), pp. 95-108. 
tayud donde a mediados del siglo XII (1154) ya se obraba en la ciudad cerámica ${ }^{47}$. En 1293, por ejemplo, ya se documenta la existencia de ollerías en Ráfales, en la zona del Bajo Aragón, al hacerse referencia a diversas rentas señoriales de las que allí disponían los calatravos de Alcañiz, entre ellas el llamado «diezmo de las ollas $\rangle^{48}$. Otra noticia es la alusiva a la renta pagada, en 1294, por los moros de Huesa del Común, al norte de la actual provincia de Teruel, por cada hornada de ollas, seis dineros concretamente ${ }^{49}$. Entre otras referencias pertenecientes a Almonacid de la Sierra, Gotor, Villanueva de Jalón, Fuentes de Ebro, Chodes, Huesca, Barbastro, Calanda, etc. que evitaremos citar para no alargar demasiado el comentario. Sin embargo, no cabe duda que ya desde la primera mitad del siglo XIV, Teruel se convirtió en el principal abastecedor de cerámica de mesa de todo el sur de Aragón. De hecho, escudillas de la serie verde y blanco y, en menor medida, platos decorados en verde y morado llegan sin dificultad por entonces a casi cualquier lugar habitado de la propia comunidad de aldeas de Teruel y otros dominios señoriales aledaños.

Estas formas cerámicas turolenses, no obstante, variaron significativamente a lo largo de toda la Edad Media. Las producciones más antiguas que conocemos, de la segunda mitad del siglo XIII, presentan una marcada influencia musulmana no exenta, sin embargo, de novedades. Platos y fuentes de mediano tamaño, similares a los ataifores que por entonces se producían en Al-Andalus, conviven con ollas de intenso color gris, parecidas a las que se fabricaban desde antiguo en los reinos cristianos durante los siglos XI y XII. A ellas se añaden formas nuevas, como las escudillas lobuladas, los platos planos y los picheres. Este repertorio fue evolucionando con el tiempo, especialmente a partir de mediados del siglo XIV. Aparecen entonces jarras de varias asas y picheres de base plana y un conjunto de formas cada vez más estandarizadas y sencillas de realizar.

Las decoraciones empleadas fueron sumamente variadas. Las más complejas pertenecían a la cerámica esmaltada de mesa, para la que se utilizaron varias soluciones cromáticas, destacando al principio la combinación de colores blanco,

47. Sobre esta producción cerámica no volvemos a encontrar nuevos datos sino hasta finales del siglo xV y en los comienzos del xvi. En estas fechas, los documentos designan a algunos alfareros mudéjares como malequeros, término con el que se nombraba al que producía «obra de Málaga», o lo que es lo igual, loza dorada. Calatayud se convertiría en uno de los centros pioneros de la industria de reflejo metálico, que es, dentro de la cerámica decorada, la especialidad más difícil y la producción más cara.

48. Laliena Corbera, C., Sistema social, estructura agraria y organización del poder en el Bajo Aragón en la Edad Media (siglos XII-XV), Teruel, Instituto de Estudios Turolenses, 1987, p. 103. La alfarería de Ráfales debió alargarse durante toda la Edad Media y Moderna hasta llegar a finales del siglo XIX.

49. García Marco, F. J., «Fiscalización, feudalismo y señorío en el mudejarismo aragonés a través del ejemplo de las comunidades del Jalón y del Jiloca medios (siglos XII al XVI» en Actas del V Simposio Internacional de Mudejarismo, Teruel, 1991, pp. 41-63, en concreto se menciona en la p. 53. 
verde y morado. Los temas más habituales procedían de la estética andalusí, pero también de la heráldica señorial (escudos, leones rampantes, caballeros, etc.). A partir de finales del siglo XIV comenzó a producirse, además, cerámica decorada en azul y blanco con un repertorio ornamental muy relacionado con el de los talleres valencianos.

La cerámica de Teruel, sobre todo la esmaltada, tuvo gran aceptación en toda la mitad sur de Aragón, exportándose en cantidades importantes a lugares alejados, ya desde principios del siglo xIv. De este forma, desde Zaragoza a Valencia, o desde las villas fronterizas de Castilla (Medinaceli o Molina de Aragón) al Maestrazgo, es posible encontrar cerámica bajomedieval elaborada en los obradores de dicha ciudad.

Los datos relativamente abundantes que luego veremos sobre la exportación de cerámica de Teruel a toda la mitad meridional del reino, a Valencia y a puntos intermedios en la ruta entre ambas ciudades podrían ser el testimonio de un auge en la comercialización, que explicara la homogeneidad morfológica que sufren las producciones turolenses, acompañado de una significativa reducción de la complejidad formal de los tipos cerámicos, que tienden con el paso del tiempo a presentar perfiles más sencillos y, en principio, de más rápida elaboración.

Un último apunte va referido a la cerámica de Muel. Esta localidad, en su etapa mudéjar, se inicia como destacado centro de producción cerámica a fines del siglo Xv, aunque quizás procedieran de sus alfares la azulejería que se hizo para el palacio de la Aljafería de Zaragoza (siglo XI) y las piezas monocromas y azulejos heráldicos que se colocaron en el muro exterior de la catedral de La Seo (1375-80); a pesar de todo, su más destacada producción es el reflejo dorado, color que a menudo aparece unido a otro azul o incluso al verde.

Tras la expulsión mudéjar, los alfares aragoneses (principalmente, Calatayud, Teruel y Muel) quedaron prácticamente despoblados. Sin embargo, la urgencia del abastecimiento de los mercaderes aragoneses fue una de las razones que condicionaron la inmediata instalación de otros artífices, ahora cristianos, en estas y otras localidades. Ellos fueron quienes dirigieron su segunda etapa de producción, período que concluiría definitivamente con su extinción, acaecida entre fines del siglo XIX y principios del XX.

\section{INTERCAMBIOS Y TRANSFERENCIAS DE LA CERÁMICA ENTRE ARAGÓN Y VALENCIA}

La importancia de los aspectos comerciales de las cerámicas medievales deriva precisamente de ser un buen indicador de la tónica comercial de una zona dada en un determinado momento. El carácter básico de la cerámica para cubrir necesidades relacionadas con la reproducción diaria de las unidades domésticas y el hecho de haber sido relativamente accesible, hizo que la cerámica se difun- 
diera social y geográficamente entre amplias capas de la sociedad y grupos de población. Una investigación atenta de los rastros dejados por esta difusión y los mecanismos empleados para llevarla a cabo podría aportar datos reveladores para el estudio del comercio bajomedieval en general. De todas formas, no seremos tan ambiciosos, de modo que el análisis de las formas de comercialización de la cerámica entre Aragón y Valencia creemos que planteará algunas cuestiones generales que permitan ulteriores avances.

\subsection{Los canales, redes y ámbitos comerciales}

Ciertamente, la capacidad de la cerámica medieval del sur de Aragón es restringida, incomparable con la de los productos levantinos, integrados en redes comerciales que llegaban desde Alejandría hasta las Islas Británicas y desde el norte de África hasta los Países Bajos ${ }^{50}$. En cualquier caso, es seguro que desde finales del siglo XIII o, más bien principios del XIV, las producciones cerámicas del sur aragonés participaban en circuitos comerciales que necesariamente implicaban la labor de intermediarios. Sólo así se puede entender su llegada a lugares como Novallas (Zaragoza), en la zona del Moncayo, o a Molina de Aragón (Guadalajara), donde la homogeneidad y abundancia del material arqueológico allí recuperado deja bien claro que no se trataba de una llegada ocasional de piezas aisladas, sino de un auténtico flujo comercial. Pero, para el caso que más de cerca nos incumbe, la cerámica turolense sobre todo, llegaba hasta Valencia, donde el conocido inventario de los bienes de Miguel Loret, fechado en 1319, deja claro además qué formas de mesa, sobre todo escudillas y tajadores, llegaban ya por entonces a la capital levantina, fenómeno que parece tener además apoyo arqueológico ${ }^{51}$.

La vitalidad de este comercio debió mantenerse firme durante toda la mitad del siglo XIV, seguramente empleando las mismas rutas y canales comerciales que desde Valencia comenzaban a hacer llegar al valle del Ebro las producciones de azul y reflejo dorado levantinas.

Zaragoza, a pesar del desarrollo de sus producciones locales durante la segunda mitad del siglo Xv, continuó siendo un habitual receptor de producciones turolenses. Las terraças de Teruel llegaban a finales del siglo Xv, como pone de

50. Sobre la importancia de las exportaciones valencianas a la península itálica, veáse VV.AA., Penísola Iberica e Italia: rapporti e influenze nella produzione ceramica dal medievo al XIII secolo. Atti XXXI Convegno Internazionale della Ceramica (Albisola 29-31 mayo 1998), Albisola, Centro Ligure per la Storia della Ceramica, 1999; y para la llegada de estas cerámicas a la zona atlántica,. GerRARD, C. M, GutiÉrRez, A., y VINCE (eds.) A. G., Spanish Medieval Ceramics in Spain and the British Isles, Oxford, BAR Series, 1995.

51. Olivar Daydí, M., La vajilla de madera y la cerámica de uso en Valencia y Cataluña durante el siglo XIV (según los inventarios de la época), Anales del Centro de Cultura Valenciana, Anejo 2, Valencia, 1950, doc. II, p. 25; y LeRMA, J. V., «Loza gótico-mudéjar medieval» en Revista de Arqueología, 65 (1986), pp. 29-40, en concreto p. 33 . 
manifiesto el inventario de una botica zaragozana en $1488^{52}$. Lo mismo ocurría con Valencia, donde también han podido ser recuperadas diversas piezas fechables en varios momentos del siglo $\mathrm{XV}^{53}$. Ciertos tipos de piezas de producción turolense resultaban relativamente frecuentes durante toda la segunda mitad de esta centuria en algunos puntos de la ruta que unía a Teruel con Valencia, incluyendo Segorbe. Un inventario procedente de esta localidad, el de los bienes de la casa del pelaire Luis Gómez, alias Serrano, de 1488, incluía, en el comedor de la vivienda, además de varios platos, escudillas de Maliqua, piezas procedentes de Teruel, entre ellas tres terracetes terolanes, un llibrellet terolá y hun terraz e una terraçeta terolanes, a lo que debe añadirse quatre morters de terra los dos terolans, localizados éstos en la bodega de la casa ${ }^{54}$. La zona del valle del Palancia estaría dentro del área de influencia de los talleres próximos a Valencia, fundamentalmente Paterna y Manises, pero también estaría directamente conectada con la producción proviniente de Teruel, tal y como muestran algunas prospecciones arqueológicas realizadas en una alquería de Ahín (Benialí), habitada entre 1432 y $1526^{55}$.

Con los datos que acabamos de ver, la geografía comercial de la cerámica bajomedieval de Teruel dibuja un área que abarca todo el sur de Aragón, sobre todo las serranías ibéricas, incluyendo las poblaciones castellanas más cercanas, además de toda la ruta que desde Teruel se dirigía hasta la propia Valencia. Esta distribución no es arbitraria; responde a factores bien precisos, relacionados sobre todo con el tipo de mercader que intervenía en el comercio cerámico, relativamente modesto en comparación con los que participaban en la exportación de la cerámica de Manises. A ello hay que unir además aquellos factores que limitaban la capacidad comercial de estos intermediarios. Entre ellos, la situación interior del propio lugar de producción, aunque queda claro que no cabe reducir toda la problemática del comercio medieval del sur de Aragón a determinismos geográficos.

Debemos señalar como hipótesis la posibilidad de que parte de la comercialización de las cerámicas del sur de Aragón se hiciera como producto subsidiario del comercio de lana y tejidos, cuyos mercaderes valencianos o catalanes, junto a otros zaragozanos y vascos, comienzan a ser documentados en Teruel, por ejem-

52. Cfr. González Martí, M., Cerámica del Levante Español..., citado, p. 598.

53. Lerma, J. V., y otros, La cerámica gótico-mudéjar..., citado, $\mathrm{n}^{\circ}$ 42-44.

54. Archivo de la Catedral de Segorbe, Protocolo 715, vol. 2 (1488-VI-30).

55. Rosas Artola, M., «La ceràmica dels segles XV-XVI. La transició a l'etat moderna» en Actas del IV Congrés d'Història i Filologia de la Plana, 1996, pp. 34-57, concretamente en las pp. 43-44. 
plo, desde finales del siglo XIII ${ }^{56}$. En cierta medida, la situación podría recordar a la fuerte vinculación que existe entre los sastres valencianos y los alfareros de Paterna y Manises, como vimos ${ }^{57}$; o entre la manufactura del lino y la del barro en Segorbe a principios del siglo $\mathrm{Xv}^{58}$.

Cuando nos referimos a las producciones no vidriadas, es decir, aquellas no necesariamente integradas en canales de abastecimiento de óxidos destinados a impermeabilizar y decorar algunas de las piezas de cocina y prácticamente todas las que servían para presentar los alimentos en la mesa, parece más que probable que hubiera existido una red de pequeños obradores locales, productores de lo que conocemos como «cerámica común». No conocemos apenas nada sobre la existencia de alfarerías en Albarracín o en Alcañiz, aunque la existencia de ollerías en Daroca es mencionada ya desde época temprana, un dato que seguramente es extrapolable a otros núcleos de cierta entidad demográfica ${ }^{59}$.

Otro factor de limitación de la comercialización de las cerámicas producidas en los alfares de Teruel lo constituye la producción catalana. Las referencias que tenemos al respecto son escasas, pero inequívocas, por ejemplo para la llegada a Zaragoza de ollas vidriadas desde Tortosa en 1380 y desde Barcelona hacia $1497^{60}$. El hecho no tiene nada de especial, teniendo en cuenta el papel jugado por Zaragoza en el entramado mercantil de la Corona. Igualmente significativo es el ejemplo de Alcañiz donde la cantarería presenta significativas conexiones con producciones de Lérida.

Si la llegada de cerámica turolense a Valencia es, como hemos podido ver, innegable, también lo es el buen mercado que la levantina tuvo en todo el reino de Aragón. Incluso en áreas relativamente alejadas, como la ciudad de Jaca, las cerámicas doradas de las primeras fases de actividad de los obradores maniseros hasta las típicas de principios del siglo xv, han podido ser constatadas junto a piezas de Paterna esmaltadas en blanco y azul. Es normal por lo tanto encontrar con relativa frecuencia cerámica valenciana en Zaragoza, no sólo en diversas excavaciones arqueológicas, sino también en un buen número de inventarios. La lista podría alargarse, añadiendo un buen número de poblaciones, pero bastará

56. Gargallo, A., «Teruel en la Edad Media: de la frontera a la crisis (1171-1348)» en Teruel mudéjar. Patrimonio de la Humanidad, Zaragoza, 1991, pp. 9-105, en concreto pp. 62 y 83-89; y El Concejo de Teruel..., citado, t. II, pp. 498-527.

57. Según López Elum, P., Los orígenes de la cerámica..., citado, p. 40.

58. En este sentido, véase APARICI, J., «Actividad artesanal de los musulmanes segorbinos...», citado, p. 38.

59. Gargallo Moya, A., El Concejo de Teruel en la Edad Media, 1177-1327, Teruel, 1996, t. III, p. 670.

60. González Martí, M., Cerámica del Levante Español..., citado, pp. 577, 581 y 590. 
con citar algunos ejemplos de los que tenemos referencia publicadas, caso de Castiliscar, Ateca, Cetina, Calatayud o Alcañiz ${ }^{61}$.

Incluso Teruel recibe cerámicas de este tipo y lo hace desde las primeras fases de actividad de los alfares de Manises. La importación de cerámicas desde el levante peninsular en estos momentos se reducía casi en exclusiva a las típicas producciones doradas. La llegada de piezas decoradas en verde y morado, más difícil de detectar por los parecidos técnicos y decorativos que guardan durante esta primera mitad del siglo XIV las cerámicas de Paterna y Teruel, hasta el momento no ha podido ser confirmada, aunque existen indicios que permiten pensar en esta posibilidad.

La llegada de material valenciano a partir del último cuarto del siglo XIV es regular. Prueba de ello es el conjunto arqueológico hallado en Fortanete, en pleno Maestrazgo, quizá el mejor ejemplo del tráfico de cerámica valenciana existente en este momento. Se trata de un lote formado por escudillas y platos decorados en azul y reflejo metálico, que llegaron a la localidad muy posiblemente aprovechando las rutas y flujos de intercambios empleados por el comercio de lana. Todos estos hallazgos pertenecen a un período enmarcable entre 1390 y $1420^{62}$.

Esta llegada regular, aunque siempre en pequeñas cantidades, de cerámica valenciana a Teruel tiene otra vertiente que merece la pena investigar y que está conectada con la existencia de piezas e incluso series decorativas completas inspiradas por las producciones levantinas. Bastaría con poner el ejemplo del término obra de Maliqua con que se conocía a la cerámica de reflejo dorado de Manises para darnos cuenta de ello. El impacto de esta producción tuvo repercusión hasta tal punto que llegó a inspirar directamente toda la serie azul de la cerámica tardomedieval de Teruel, justamente cuando la comercialización de la producción de Manises comenzaba a decrecer en todo el reino de Aragón, ante la pujanza de nuevos centros productores ya establecidos, especialmente el de Muel. De nuevo, la ausencia de un marco técnico apropiado para la producción y comercialización de cerámica dorada llevó a los alfareros turolenses a imitar con

61. Respectivamente, Rey LanasPa, J., «Excavaciones en el castillo de Castiliscar (Zaragoza)» en Arqueología Aragonesa 1992, Zaragoza, 1994, pp. 137-143; Baquedano Pérez, E. y Martínez García, F., «Memoria de excavación en el Castillo de Ateca» en Arqueología Aragonesa 1994, Zaragoza, 1997, pp. 187-190; Souto Lasala, J. A., «Excavación del patio del Palacio de Cetina (Zaragoza) y estudio de sus cerámicas medievales» en Boletín de Arqueología Medieval, IV (1990), pp. 255-283; Cebolla, J. L., Royo, J. I., y Rey, J., La arqueología urbana en Calatayud. Datos para una síntesis, Calatayud, 1997, p. 214; Álvaro, Ma. I., «La cerámica decorada del castillo de Alcañiz» en J. A. Benavente (coord.), El castillo de Alcañiz. Al-Qannis, 3-4 (1995), Alcañiz, pp. 91-152.

62. Atrián Jordán, P., «Hallazgo de cerámica medieval en Fortanete» en Teruel. Boletín informativo de la Diputación Provincial, 41 (1981), pp. 23-25. 
óxido de cobalto, cuyo abastecimiento para entonces ya era habitual, las formas y motivos empleados en Manises con la cerámica dorada ${ }^{63}$.

\subsection{Comercialización de la cerámica a través de las aduanas del General}

El comercio de la cerámica a través de la frontera terrestre entre Aragón y Valencia, tema que nos ocupa, fluye por medio de los numerosos puestos aduaneros aragoneses que jalonan dicho territorio fronterizo y que limitan directamente con el reino levantino, destacando de sur a norte los siguientes: Arcos de las Salinas, Torrijas, Almansa, Albentosa, San Agustín, Olba, Fuentes de Rubielos, Linares de Mora, Puertomingalvo, Mosqueruela, La Iglesuela del Cid, Mirambel, La Cuba, Tronchón, Bordón, Luco, Aguaviva, La Ginebrosa, Torre de Arcas, Monroyo, Peñarroya de Tastavíns y Valderrobres. Entre ellos sobresale, tanto por la importancia del tráfico registrado como por ser una de las collidas de mayores ingresos, la de Barracas de los Jaqueses, en función de la constatación del fluido tráfico comercial con Levante a través de la vía natural del puerto en el curso alto del Mijares, explicando a su vez la modestia de la recaudación de las otras collidas por las complicadas comunicaciones existentes en el resto de la frontera.

La consulta de documentación fiscal de la sección Generalidad del Archivo de la Diputación Provincial de Zaragoza nos ha permitido comprobar que esta corriente importadora de cerámica desde el reino de Valencia hacia Aragón alcanzó palpable desarrollo en el transcurso del siglo XV. Las fuentes fiscales a las que remitimos principalmente son los libros de aduanas del General, que para el caso de la collida de la tabla de Barracas de los Jaqueses atesora tres manuscritos de época medieval (con los números 26, 15 y 30) correspondientes a los ejercicios 1444-45, 1445-46 y 1446-47 respectivamente ${ }^{64}$. Se trata de un conjunto de libros contables consecuencia del cobro del impuesto de Generalidades a todas las mercancías que transitaban por las fronteras del reino de Aragón, tanto en sentido importador como exportador, cualquiera que fuera la persona que transportase los productos, el origen o el destino.

Procedentes del Levante vienen por la meseta turolense varios materiales cerámicos. La obra se refería a un conjunto de objetos trabajados y muy especialmente los de barro; mientras que como obra de terra se entendía al nombre genérico que en la documentación bajomedieval se daba a la producción cerámica en general o, lo que es lo mismo, a un conjunto de manufacturas de arcilla:

63. Ortega, J., «Producción artesanal, transferencias comerciales...», citado, pp. 78-83.

64. Archivo de la Diputación Provincial de Zaragoza (A.D.Z.), Secc. Generalidad, Libros de la Collida del General de la Tabla de Barracas, correspondiente al ejercicio 1444-45, Ms. 26, Legajo 70, 246 hojas; año 1445-46, Ms. 15, 272 hojas; y, año 14446-47, Ms. 30, 275 hojas, libros en papel, encuadernación en pergamino. 
ollas, escudillas, cántaros, tejas, ladrillos, platos, tinajas, lebrillos, jarras, vasos, coberteras y hasta candiles. La tierra, barro o arcilla constituía la materia prima para las manufacturas de arcilla, loza y porcelana y también para batanar y desengrasar los tejidos (tierra de batán o de pipa) ${ }^{65}$.

En la siguiente tabla aparecen recogidas las importaciones de obra que desde Barracas ingresaron en Aragón, aunque debemos señalar que también hubo tres partidas de exportación de obra de tierra, en las cuales no se especifica cantidad. Al igual que en la collida de Arcos de las Salinas por donde entran otras tres partidas, dos de obra de tierra y una de obra de Málaga.

\section{Distribución anual de las importaciones de «obra» declaradas en la aduana de barracas}

\begin{tabular}{|c|c|c|c|c|c|}
\hline \multirow{2}{*}{ Ejercicio } & \multirow{2}{*}{$\mathrm{N}^{\circ}$ partidas } & \multirow{2}{*}{ Cantidad } & \multicolumn{3}{|c|}{ Valor } \\
\hline & & & Libras & Sueldos & Dinero \\
\hline $1444-45$ & 216 & $\begin{array}{l}630 \text { ' } 5 \text { gruesas, } 177 \text { docenas, } \\
7 \text { capazos, } 1 \text { cesta, } 7 \text { costales, } \\
1 \text { banasto y } 1 \text { carga }\end{array}$ & 355 & 13 & 9 \\
\hline $1445-46$ & 159 & $\begin{array}{l}386 \text { gruesas, } 162 \text { docenas, } \\
45 \text { capazos, } 1 \text { cesta, } 44 \text { costales, } 8 \\
\text { piezas, } 1 \text { canasta, } 1 \text { cestaño y } \\
1 \text { sarrieta }\end{array}$ & 239 & 18 & 6 \\
\hline \multirow[t]{2}{*}{$1446-47$} & 294 & $\begin{array}{l}525^{\prime} 5 \text { gruesas, } 124^{\prime} 5 \text { docenas, } \\
21 \text { capazos, } 1 \text { cesta, } 8 \text { banastos, } \\
1 \text { carga, } 169 \text { costales, } 3 \text { piezas, } \\
3 \text { cestaños y } 222 \text { sarrietas }\end{array}$ & 560 & 3 & 11 \\
\hline & TOTAL & $\begin{array}{l}1.542 \text { gruesas, } 463 \text { ' } 5 \text { docenas, } \\
52 \text { capazos, } 3 \text { cestas, } 51 \text { costales, } \\
9 \text { banastos, } 2 \text { cargas, } 11 \text { piezas, } \\
1 \text { canasta, } 4 \text { cestaños y } 223 \text { sarrietas }\end{array}$ & 1.155 & 16 & 2 \\
\hline
\end{tabular}

Confluían en las distintas aduanas aragonesas fronterizas productos cerámicos de calidad procedentes de importantes áreas de producción que, ubicadas en torno a esta geografía en el itinerario que unía las tierras valencianas con las de Teruel, entre sus variantes sobresalían la de Málaga (32.910 piezas y una carga), contrafets o escontrafechas, es decir, obra falsificada, imitada, de mala calidad (1.584 piezas), cardenilla (8.340 piezas), de vidre -término dado en ocasiones a la cerámica de reflejo dorado de Manises- (3.240 piezas), de henperador (576 piezas), etc. De la misma manera, resulta representativa aquella cerámica de la

65. Gual Camarena, M., Vocabulario del comercio medieval: colección de aranceles aduaneros de la Corona de Aragón (ss. XIII-XIV), Tarragona, 1968, p. 439. 
que no se especifica su procedencia (obra de tiera), cuya cantidad correspondería al resto de la declarada.

Una primera observación de los datos nos muestra dos puntos interesantes: todos los meses del año entra cerámica en Aragón y el precio de algunas variedades ofrece oscilaciones durante los tres ejercicios anuales (entre 10 sueldos la gruesa de obra de tierra y 12 la de Málaga, siempre mejor estimada).

Entre los personajes que comercian con obra en la aduana de Barracas, destacamos durante el primer ejercicio a Juan de Serón con 19 gruesas y media de obra de tierra al precio de 11 libras (1445-I-14); en el segundo sobresale Juan Lana declarando 18 gruesas y 4 docenas, valoradas en 12 libras 6 sueldos (1446IV-12); y en el tercero, Martín de Cañamache con 26 gruesas 1 docena al precio de 15 libras (1447-V-7) y él mismo con 23 gruesas 10 docenas que cuestan 17 libras (1447-VI-26).

La existencia de cerámica de varios centros productores es algo frecuente, e indistintamente representa diversas tipologías cerámicas, si bien notamos una mayor presencia de los elementos de Málaga, no sólo en relación a su número sino también por su calidad por el uso decorativo que se le da. Posiblemente por ello, la cerámica de Paterna-Manises (obra de Malica, Maliqa, Meliga) resultó ser un elemento común y asíduamente inventariado en las declaraciones. También lo fue la llamada tierra de Sevilla que se emplearía en alfarería para conseguir el color ocre y que se produciría, especialmente, en las regiones del norte del Sur de Aragón, por lo que es la aduana de Montalbán ${ }^{66}$ la que registra un mayor control de su comercio al anotar en el ejercicio 1446-47 un total de 175 arrobas, es decir, unos $2.100 \mathrm{~kg}$., con un precio que llega a los 10 sueldos la arroba; mientras que en Barracas únicamente 1 quintal y 4 arrobas atraviesan la frontera durante el ejercicio de 1445-46, además de dos partidas en las que se mezcla con tierra de Gales; y también en otras dos ocasiones nos aparece la tierra de Flandes, de donde se obtuviera, posiblemente, un pigmento similar a la tierra de Sevilla. Y, junto a ella, la llamada tierra morena o negra, que como se especifica en alguna partida, se utilizaba «para esbromar e templar el vidrio», siendo Valbona y también Montalbán, los puntos de salida, lo que nos marca destinos diversos. Por Barracas cruzan un total de quince partidas de entrada, que suman 35 docenas de capazos, 2 gruesas, 1 carga, 3 quintales, 10 arrobas, 27 libras y un lebrillo de tierra, valorados en 43 libras 18 sueldos 5 dineros. Como clases, además de las citadas en nuestras fuentes, tenemos las de Paterna y Cárcer, además de tierras rojas, grasas, de «compte»y de «pinzell».

66. A.D.Z., Leg. 582. 
De las ollerías de las diferentes villas y ciudades salía una gran diversidad de productos, como tinajas para almacenar líquidos, horzas para guardar alimentos en conserva y cántaros para transportar vino, etc. Dentro de la cerámica encontramos, además, tres tipos o especialidades principales, que se suceden, de acuerdo con un orden de menor a mayor dificultad en su elaboración: la alfarería «de agua» o cantarería, la alfarería «de fuego» u ollería y la que podemos denominar cerámica decorada.

De esta manera, comenzamos nuestro estudio por las piezas cerámicas que atravesaron las distintas aduanas, empezando por los productos empleados en la preparación de alimentos.

En primer lugar, destacamos las ollas, destinadas a la cocción de alimentos, normalmente destinadas a cocinar no más de cinco raciones. Así, por la aduana de Barracas ingresan durante los tres ejercicios fiscales conservados más de dos millares y medio de ollas, cuyo coste oscila alrededor de 4 sueldos la docena. Otra de las piezas más significativas son los morteros, cazos y cazuelas, que podían fabricarse en latón o cobre, pero también de tierra.

Seguimos nuestro amplio repertorio de formas, con aquellos objetos dedicados a servir la comida en la mesa. Siendo la más frecuente la escudilla, una especie de cuenco empleado para tomar caldos, sopas y potajes. A título orientativo, son casi 4.000 las escudillas que entran en Aragón procedentes del levante peninsular a través de la aduana de Barracas, valoradas en 50 libras 12 sueldos 10 dineros. También recogemos la presencia de altamías, en este caso, solamente en una mención a dos registros de entrada de la aduana de Barracas durante el primer ejercicio fiscal, protagonizados por Domingo Fortún (1444-IX-3) y Sancho López (1444-XII-18), quienes transportan un total de media docena el primero y docena y media el segundo. Este término, frecuente en Castilla, pero no en la Corona de Aragón, designa con bastante probabilidad algún tipo semejante a la escudilla.

A diferencia de los alimentos cocidos que solían presentarse en la mesa en las citadas escudillas, es decir, listos para ser consumidos individualmente por cada uno de los comensales, los alimentos más sólidos, que constituían la base de las pitanzas, se presentaban sobre una especie de bandejas o fuentes planas de mediano y gran tamaño, los tajadores, donde, como su mismo nombre indica, se procedía a servir y trocear carnes y pescados asados, cortando porciones con ayuda de un cuchillo. Llama la atención como desde Barracas solamente ingresan en dirección Aragón un total de cinco tajadores, tres de ellos transportados por Andrés de Calatayud (1446-VI-12) y los otros dos restantes, estos últimos de madera, pertenecientes a Juan Martín (1447-II-1). La razón de ello hay que buscarla, quizá, en que su definición quedaría adaptada no tanto a la ya señalada, 
cuanto a una especie de plato trinchero de madera que se empleaba en las matanzas para picar la carne ${ }^{67}$.

Como intermediarios entre las escudillas y los tajadores, están los platos, conocidos con diferentes denominaciones como plat, plaer o platon, solían ser de materiales lujosos sobre todo en la mesa de los más pudientes, a menudo de plata o vidrio. No obstante, existían también ejemplares cerámicos, como los 38 introducidos por la aduana de Barracas a mediados del Cuatrocientos. Frente a esta cifra bastante escasa, tenemos constatados casi 5.000 ejemplares de plateles, especie de platos o bandejas. También los gredales (griales) son muy abundantes en la documentación fiscal consultada (casi 2.800 piezas que se introducen en el reino aragonés a través de esta collida), y presentan una funcionalidad muy similar al uso del plato o la escudilla.

Quedaría por tocar el tema de los condimentos y acompañamientos de las pitanzas. Los objetos usualmente empleados para este fin reciben denominaciones como salero, salsero y salseruquo o salseruelo. Son piezas destinadas a la presentación en la mesa de salsas especiadas, aunque en el caso del último término podía referirse a la taza pequeña empleada para mezclar colores. Un total de 30 saleros y 865 salseros, junto con 12 gruesas y media, ingresan por Barracas durante el período comprendido entre 1444-47.

Para servir la bebida, se empleaban jarros de diferentes tipos. La documentación, a pesar de ello, únicamente recoge referencias a un único término, el de picher, en alusión al marcado pico vertedor que solían presentar, relacionándolo principalmente con el consumo de vino. El volumen de entrada registrado en Barracas corresponde a 45 docenas, 105 unidades y 3 gruesas de picheles, valorados en un total de 48 libras 14 sueldos 3 dineros. La funcionalidad de las jarras, en cambio, estaba claramente relacionada con el almacenamiento doméstico de agua. Por lo que respecta al terrazo -vasija de barro con un asa-, los inventarios de la época aluden a que son usados para agua y para vino, aunque no hay que descartar la posibilidad de que fueran empleados para contener aceite o miel. Hay que distinguir el centenar de terrazos consignados en el puesto de Barracas, frente a las 3 terrazas, declaradas como jarras vidriadas de dos asas. De todos modos, la función de consumo directo de líquidos es la característica que define también a las redomas.

Si la función principal de los jarros y picheres era el transporte del vino desde la bodega de la casa y el servicio en la mesa, lo usual es que se emplearan distintos tipos de vasos, tazas y copas para un consumo directo. De esta forma, tenemos contabilizados un total de 27 vasos, frente a 26 tazas constatadas en la 
aduana de Barracas durante los tres ejercicios fiscales. Igualmente ingresan por dicha aduana 20 albornias, vasija grande de barro vidriado en forma de taza, transportadas por Alí Bolax el 19 de septiembre de 1445.

Existen, asimismo, algunas formas con funciones domésticas, aunque no directamente culinarias, que conviene no dejar a un lado, dada su frecuencia. Me refiero en concreto a los lebrillos y a los candiles. Los primeros fueron también identificados en la documentación cotejada con el término conqua, esto es, cuencos o recipientes grandes utilizados para diversos usos. Y los segundos, son objetos utilizados para procurarse la iluminación de la vivienda, fabricados por lo general de cobre, latón, alambre o madera, pero también, porque no, de tierra.

Otro tipo de funciones debían cubrír los bacines, otro de los elementos que plantea dificultades de interpretación. Para empezar, su aparición en la documentación escrita de Teruel está relacionada con un uso muy concreto; majar la cal en obras de construcción. Así, en 1335, en las obras de la Catedral de dicha ciudad, se hace referencia a un baçin de tierra y en las de San Marcos, de 1456, vuelve a mencionarse con idéntico destino ${ }^{68}$. A pesar de estas noticias, sospechamos que su función usual no era preparar la cal. Es posible que su forma y función estuviera en relación con la higiene personal, similar a los ejemplares levantinos y mallorquines. Aunque la documentación zaragozana parece confirmar que en Aragón el término bacin era empleado para hacer referencia a una especie de bandeja, mientras que la bacia era un objeto de carácter mucho más cotidiano, generalmente destinado a amasar o a pisar la uva, posiblemente de forma similar a los lebrillos.

Podemos acabar el repaso por la cerámica destinada al transporte y almacenaje. Tan sólo los cántaros pueden ser caracterizados con cierta precisión, tratándose en la mayoría de los casos de ejemplares, cuya forma servía para ser utilizados como medida. A partir del siglo XIV en su mayoría rondan los 11,7 litros de capacidad, aunque esta mesura quizá responda tan solo a uno de los varios tipos de medida existentes ${ }^{69}$. En la aduana de Barracas aparecen registrados un total de 25, estimados en 11 sueldos 8 dineros. Asimismo, las tinajas eran vasijas de barro cocido de gran capacidad, empleadas con diversos usos, casi siempre relacionados con la conservación de líquidos; son únicamente 6 las que ingresan desde Barracas durante el último ejercicio de 1446-47, al precio aproximativo de

68. C. Tomás Laguía y S. Sebastián López, «Notas y documentos artístico-culturales sobre Teruel medieval» en Teruel, 49-50 (1973), pp. 67-109, en concreto p. 93. Y A. Mur i Raurell, La encomienda de San Marcos. La Orden de Santiago en Teruel (1200-1556), Teruel, 1988, doc. 64, pp. 375, 376, 377 y 385.

69. En Huesca, por ejemplo, en 1489 se diferenciaba entre cántaros mayores, medianos y chicos (Álvaro, M ${ }^{\mathrm{a}}$ I., «El trabajo en los alfares mudéjares aragoneses...», citado, p. 106), al igual que ocurre en Paterna (AmIGUES, F., «La ceramique domestique des ateliers mudejares...», citado, tabla 1). 
un sueldo la unidad. Otro artículo eran las orzas que, por su propia funcionalidad, centrada en el almacenamiento de alimentos en coserva, estaban caracterizadas por presentar un cuerpo panzudo estrechado en la base y un corto cuello destinado seguramente a facilitar su cierre mediante tapaderas, sirviéndose bien de cueros o de telas atadas o, más bien, con tapas de madera. En dicho puesto fronterizo, tan sólo hemos constatado la presencia de un ejemplar, portado por el moro Avdalá el Ruvisco el día 19 de abril de 1447, cuyo coste fue de 3 sueldos.

Pero no se agotan con lo que acabamos de comentar los tipos y funciones de la cerámica bajomedieval. Aguamaniles en forma de caballo o de cantarilla; cerámicas dedicadas a funciones culturales, desde las famosas lámparas de hannukiyya a moldes para fabricar exvotos, o pilas bautismales, por no aludir a los tinteros y escribanias, a veces de formas complicadas, que fueron también producidas en los distintos alfares e intercambiadas a través de las principales rutas y redes comerciales.

El comercio de estas tierras está principalmente en manos de mudéjares. De hecho, la continuidad de una misma familia dentro del ámbito productivo alfarero fue una constante habitual, aspecto que probablemente respondiera a la necesidad de mantener, promocionar o simplemente conservar, unos útiles, unos enseres, unos contactos, gestionados inicialmente por un miembro del linaje, y que pasarían de él a sus sucesores en dicho oficio. Posiblemente fuera una garantía o seguridad para el inicio de su actividad productiva, independiente o en ocasiones conjunta. En el caso del sur de Aragón, y dentro de la comunidad musulmana, la afinidad familiar responde a los apellidos de Arcos (Hamet y Mahoma), Caver (Hamet y Mahoma), Vera (Aziz y Hamet) y Rostrilla (Ibrahim), todos ellos olleros turolenses. En parangón con Segorbe, donde sobresalen los Xulluch (Hamet, tejero; Avdalá y Alí, rajolers; y Çahat, oller), los Sortiguero (Avdalá, arrendatario del derecho de las ollerías; Mahoma y Alí, ollers), o los Fustera (Alí y su hijo Mahoma, canterers), quienes podrían mostrar esa dinámica esbozada.

En resumen, la inmensa mayoría de la cerámica salida de los alfares medievales estaba destinada a formar parte de un sistema complejo de herramientas cuya función principal era conseguir la reproducción social de las unidades domésticas. No obstante, las ollas, cazuelas, cántaros, tinajas, platos o cuencos constituían una parte importante, aunque no única, de un sistema destinado al transporte, almacenaje y preparación de los alimentos que incluía también multitud de objetos de piedra, tejido, metal y madera. Es, por lo tanto, imposible entender de forma acabada el significado de la cerámica medieval sin intentar detectar sus relaciones con el resto de enseres que formaban los ajuares domésticos y de la conexión de todo este conjunto con las estrategias alimentarias de los diferentes grupos sociales que integraban la población. 


\subsection{Las materias primas: óxidos, pigmentos y fundentes}

La cerámica tuvo mañosos obreros que supieron sacar partido de las arcillas. De este modo, la instalación de los obradores cerámicos no ha sido arbitraria. Habitualmente se instalaron en las afueras de las poblaciones, ya que era necesario contar en las inmediaciones con alguna cantera que tuviera «vetas» $\mathrm{o}$ «barreros» de los que extraer la materia prima básica ${ }^{70}$; en puntos en los que además se debía disponer de alguna acequia, balsa o pozo donde abastecerse del agua con la que amasar y llevar a cabo el proceso de decantación. Asimismo, el alfar debía estar cercano a un paraje de monte del que poder proveerse de leña para encender los hornos en los que cocer; y debían tener una explanada de trabajo al aire libre para triturar la arcilla con rulo y asno, al margen de servir para orear las piezas.

En una alfarería debemos distinguir el trabajo de los maestros alfareros que fabrican las piezas de cerámica, las decoraban y las cocían, del trabajo de los aprendices que preparaban la arcilla, ponían a secar las piezas cerámicas y ayudaban a cargar y descargar los hornos, al tiempo que iban aprendiendo el oficio. En una misma alfarería debían seguramente trabajar varios maestros alfareros, padres e hijos, hermanos y primos; así se desprende de los documentos de venta de cerámica en que varios artesanos venden conjuntamente su obra y así parece confirmarlo la arqueología pues se han encontrado en un mismo taller distintas marcas alfareras que pertenecían a cada uno de los distintos maestros.

Además de la arcilla, los alfareros medievales necesitaban de otros componentes químicos para poder producir diferentes variedades de cerámica pintada, cerámica barnizada con vidriados ricos en óxido de plomo, coloreados o no con óxido de manganeso o cobre; y de cerámica esmaltada con vidriados al plomo que incluían porcentajes variables de óxido de estaño. Para la cerámica pintada sin vidriar, especialmente en los cántaros, donde se concentró esta técnica decorativa, lo usual era el empleo de óxido de manganeso, mezclado con agua, que se aplicaban con un pincel a las cerámicas todavía crudas, el mismo procedimiento que se empleaba en otras piezas esmaltadas. El uso de almagras a partir de óxidos de hierro, lo que le da un color miel (cerámica melada), fue sin embargo muy minoritario y sólo tuvo alguna incidencia en las primeras fases de producción. Muestra de ello son las 28 libras de almagre ${ }^{71}$ que ingresan por el puesto fronterizo de Barracas, repartidas en dos registros de entrada: el primero de 7 libras protagonizado por el declarante Gabriel de San Juan (1445-VI-11), valoradas

\footnotetext{
70. Un ejemplo del aprovisionamiento de la principal materia prima fue el declarante Juan Rubio que, el 16 de febrero de 1446, pasa por la aduana de Barracas de los Jaqueses quince libras de arcilla común al precio de 17 sueldos 6 dineros.

71. Arcilla roja empleada para hacer marcas, pintar, etc.
} 
en 1 sueldo 2 dineros; y el segundo con las 21 restantes consignadas por Adrián Viciati (1447-VII-1) al precio de 6 sueldos.

Tal vez complicado debió resultar el acceso a uno de los componentes imprescindibles de los vidriados, la galena o sulfuro de plomo, llamado alcofol en la documentación medieval y «alcohol de alfarero» todavía en tiempos recientes. En la aduana de Barracas tenemos constatado un quintal comercializado por Mahoma Huzmen (1446-II-25) y 4 libras por Alí Alí Fragi (1446-XII-8), cuyo precio es de un sueldo por libra de peso o, lo que es lo mismo, a una libra el quintal.

Es probable que el abastecimiento se realizara, bien a través de los propios mercaderes que compraban la obra a los alfareros, bien mediante diversos arrieros, como era el caso de los trajineros moros de Benaguasil, de los que sabemos que estaban especializados en el transporte de plomo al sur de Aragón, y en especial a Teruel. La noticia, por cierto, proviene de los registros de Coses Vedades, lo que es un indicativo de los problemas que pudo acarrear la llegada regular de este producto hasta los obradores de la ciudad, quizá a través de determinados tenderos o herreros. En 1420 Avdalá el Ferrero, moro de Teruel, reconocía deber al tendero Fernando García, 220 sueldos por razón de mercadería de plomo ${ }^{72}$. En todo caso, es preciso advertir que los yacimientos de galena no faltan en el sur de Aragón, concretamente en la sierra de Cucalón, en los términos municipales de Santa Cruz de Nogueras, Armillas y sobre todo en Segura de los Baños ${ }^{73}$.

Por lo que respecta al óxido de cobre, responsable de la coloración verde empleada en diversos vidriados, Almagro y Llubiá sostenían que procedía de las batiduras y de los desechos de la elaboración de calderos ${ }^{74}$. Lo cierto es que los trajineros de Benaguasil, antes citados, también solían transportar cobre a la ciudad turolense. Ha de tenerse en cuenta, además, la riqueza de yacimientos de este mineral en las cercanías de la ciudad, en especial en la Sierra de Albarracín ${ }^{75}$.

72. Hinojosa Montalvo, J., «El trabajo mudéjar en la Valencia medieval» en Actas del VI Simposio Internacional de Mudejarismo, Teruel, Instituto de Estudios Turolenses, 1995, pp. 57-83, en concreto en las pp. 80-81. La noticia sobre dicho mudéjar la tomo de las prosopografías censadas en el libro de NAVARRo, G., y Villanueva, C., Los mudéjares de Teruel y Albarracín. Familia, trabajo y riqueza en la Edad Media, Teruel, Centro de Estudios Mudéjares, 2003, p. 119.

73. Sobre estas minas, veáse GonzÁlez López J. M., Gutiérrez, M., y Simón, J. L., «Las mineralizaciones filonianas de $\mathrm{Pb}-\mathrm{Zn}$ de la región de Segura de los Baños (provincia de Teruel» en Teruel, 69 (1983), pp. 9-20. En general, Benito F., Alfaro, J., y Menéndez, J., «Memoria relativa a los yacimientos de plomo de la provincia de Teruel» en Boletín Oficial de Minas y Metalurgia, 93 (1925), pp. 99-131.

74. Almagro Basch, M., y Llubiá Munné, L., La cerámica de Teruel, Teruel, Instituto de Estudios Turolenses, 1962, p. 39; y Álvaro Zamora, Ma . I., Cerámica aragonesa I, Zaragoza, Librería General, 1976, p. 52.

75. Sobre las mineralizaciones de cobre en la Sierra de Albarracín, veáse el Mapa metalogenético de España E. 1: 200.000, Teruel, editado por el Instituto Geológico y Minero de España, Madrid, Ministerio de Industria, 1975. 
Lo contrario ocurre con el estaño, principal responsable de la opacidad de los esmaltes, y con el óxido de cobalto (el zafre de la documentación medieval, y que en otros lugares se conoce como azur), elemento con el que se consigue el tono azul del vidriado, es una materia escasa en la cuenca del Mediterráneo ${ }^{76}$, aunque parece ser que estaba presente en algunas zonas del territorio nazarí. Según afirma Portier, la mayor parte de este producto empleado en la cerámica valenciana y aragonesa, posiblemente procediera de Chóvar, en Castellón, o incluso se traía desde Venecia cuando era más escaso ${ }^{77}$. En Barracas sólo se ha contabilizado una entrada de 4 onzas de azul, personalizada en la figura de Hamet de Vera el día 11 de febrero de 1446; no es extraño si identificamos a este mudéjar turolense con el oficio de ollero que sabemos detentaría al menos durante el período 1455-1457 que tenemos prosopografiado ${ }^{78}$.

\subsection{Transporte, condiciones y precios de venta}

La producción y comercialización de la obra constituyeron procesos sucesivos, inseparables e imprescindibles para la buena marcha de un alfar. La documentación nos demuestra que aunque las formas de obrar y vender el producto cerámico fueron muy diversas, destacaron básicamente tres: la venta directa, la contratación de toda o una parte de la producción por mercaderes (aspecto que iba unido al del abastecimiento de materias primas básicas) y el encargo concreto de una obra determinada.

La venta directa fue hecha a menudo por los propios alfareros, quienes además de exponer sus piezas en los mismos obradores, también vendían la producción en tiendas o botigas anejas casi siempre a éstos o bien adquiridas para este uso. No obstante, en lo que respecta a la forma concreta de comercialización de estas producciones fuera de la ciudad, es bastante posible que algunos alfareros, sus familias o arrieros se encargaran también de la distribución de sus productos entre las aldeas, mercados y ferias más cercanas. La venta en las zonas más alejadas del área comercial capaz de ser abastecida directamente por los propios artesanos y pequeños arrieros que actuaban como revendedores, tampoco ha dejado excesivas huellas en la documentación consultada.

En todo caso, los contratos bajomedievales de venta de cerámica nos dan una serie de informaciones sobre su producción y los precios que alcanzaba.

\footnotetext{
76. Dufournier, D., Flambard, A. M. y Noyé, GH., «A propos de céramique «RMR»: problèmes de définition et de classement, problèmes de répartion» en Siena, 1986, pp. 251-278, en concreto pp. 277-278.

77. Portier, Y., «Orígenes y difusión del cobalto utilizado en cerámica en época medieval. Estudio preliminar» en Aix-en Provence, 1997, pp. 505-512, en concreto pp. 508-509; quien recoge también noticias sobre las explotaciones de la zona de Morata de Jalón (Zaragoza).

78. Consúltese Navarro, G. y Villanueva, C., Los mudéjares de Teruel..., citado, p. 148.
} 
Los alfareros trabajaban la mayor parte del tiempo sobre pedidos de los clientes, quienes especificaban la forma y el tamaño de las piezas cerámicas; a veces, sobre todo si la cerámica era decorada, entregaban un ejemplar al maestro alfarero para que éste tomara modelo sobre la forma, la decoración o el color de ésta y se estipulaba que la obra del alfarero debía ser de lo mejor y cuando menos tan hermosa como la muestra. El plazo de entrega de los pedidos variaba entre cinco semanas y dos meses; si la mercancía no estaba lista en el plazo convenido o no era de la calidad especificada en el contrato, el alfarero se comprometía de antemano a pagar una multa. A veces ésta era bastante elevada, pero en otras era más bien simbólica (por ejemplo, bastaba con un par de gallinas).

El precio era, además de una cifra económica, el resultado de la tensión producida por los intereses mercantiles, por un lado, y los intereses del común de la población, por otro. De esta forma, el precio de la cerámica variaba según los costes. Así, a comienzos del siglo Xv los alfareros valencianos pagaban el quintal de plomo a 40 sueldos, mientras que el mismo quintal solo valía 28 sueldos a mediados de la centuria; y en 1500 se pagaba el plomo a 15 sueldos la arroba y el estaño a 2 sueldos la libra de peso, lo que explica que la cerámica esmaltada (impermeabilizada con estaño y plomo) se vendiera más cara que la que iba solo barnizada con plomo. También influía en el precio las materias primas empleadas en la decoración (cobre, cobalto, plata) y la cochura: las cerámicas bizcochadas, pintadas o no en manganeso y las barnizadas se cocían una sola vez; mientras que las pintadas en verde/manganeso y en azul había que cocerlas dos veces y las que llevaban decoración azul y dorada, hasta tres veces, lo que aumentaba considerablemente el coste de combustible. Asimismo, si la decoración era de encargo con especificaciones del comprador también aumentaba su precio.

Algunos alfareros vendían sus productos mucho más caros que sus colegas por su reputación de calidad. Es por eso que para garantizar sus productos, éstos irían marcados o firmados. De ahí que se encuentren muchas piezas con marcas estampilladas en el cuello y en la boca, lugares muy visibles. En los contratos de venta el precio de la cerámica se da, por lo general, en sueldos reales de Valencia o en florines de oro de Aragón. La cerámica se cuenta por docenas y por gruesas (doce docenas, esto es, 144 piezas). La cantidad de piezas de cerámica que se vende en algunos contratos es enorme. En 1404, por ejemplo, Mahoma y Çahat Alcudo, moros de Paterna, le venden al comerciante valenciano Vicente Corts, noventa gruesas de «obra de terra de pinzell» (12.960 piezas de cerámica pintada, de las que 10.680 eran "escudelles de menjar» iguales al modelo que entregaba el comprador); la cerámica debía entregarse en el Grao de Valencia en el plazo de dos meses; el precio por gruesa se estipuló a 9 sueldos de Valencia.

En los recipientes contenedores se especificaba la capacidad, como en un contrato fechado en 1414 en el que se le pide al alfarero 720 «pots» (botes) de 
una libra y de libra y media. Las tinajas y orzas podían tener entre 10 y 40 cuartillos en 1415 o bien se especificaba que fueran tinajas u orzas «d'escudellar» (literalmente: meter escudillas) donde cupieran desde gruesa y media (150) hasta seis gruesas de escudillas (864).

Los alfareros cobraban por adelantado, lo que ellos llamaban una señal del encargo, si no todo el precio de la cerámica, si una parte importante que podía ser en dinero o en las materias primas que necesitaran para realizar el pedido, como plomo, estaño o cobalto (zafre). En el contrato de los Alcudo que hemos visto anteriormente, se les entregaba 100 sueldos por adelantado como señal y el resto al entregar la cerámica, en que recibirían 10 quintales de plomo y la diferencia en dinero.

A veces los alfareros cambiaban sus productos por objetos de uso personal, dejándonos así prueba de algunos de sus caprichos y al parecer de su buen nivel de vida; o bien, los cambiaban por otras mercancías que luego volverían a vender (normalmente animales de carga). Otras veces cambiaban su producción por trigo de Sicilia o por atún y pescado salado de Ibiza interviniendo activamente en el comercio de la época.

La producción alfarera era vendida, en muchas ocasiones, varias veces antes de llegar al puerto de Valencia para su exportación, como hemos visto en varios documentos, lo que aumentaba su precio. La producción de un alfarero podía ser comprada por un botiguero de la propia localidad, de los pueblos de los alrededores o incluso de otras tierras más alejadas a la frontera del reino, quien la vendía al comerciante de cerámica, establecido en Valencia, o en su caso en Aragón. Éste, si no la exportaba él mismo, se la vendía al armador o comerciante de la nave que la llevaría a otros puertos para venderla nuevamente. Es así como en los primeros años del siglo XVI el concejo de Paterna prohibió la reventa de sus productos alfareros para evitar los intermediarios y el subsiguiente aumento de precio, pero en 1520, cuando la ciudad de Valencia pasó a ser propietaria de esta baronía, decretó que la venta de la «obra de terra» de Paterna fuera libre, pudiendo quienquiera comprarla y traerla a Valencia ${ }^{79}$.

Los comerciantes de Valencia exigían casi siempre que la cerámica les fuera entregada en el puerto de Valencia, corriendo el embalage y el transporte por cuenta y riesgo de los alfareros. En muchos contratos se estipula como deben ir embaladas las cerámicas: la vajilla fina (obra de pincell o de malica) debe ir «ingerrata», es decir, dentro de tinajas más o menos grandes según la cantidad a transportar. Los documentos hablan de «gerres» 0 《gerretes». Conocemos varios hallazgos en el Mediterráneo occidental de estas tinajas llenas todavía de

79. Mesquida García, M., «Un pueblo alfarero medieval: Paterna (Valencia). Estudio etno-arqueológico y documental» en Actas de las I Jornadas de Cerámica Medieval e Pós-Medieval. Métodos y resultados para su estudio, Tondela (Portugal), 1992, pp. 229-245. 
cerámicas. Recordemos, por ejemplo, la que se halla en el Monasterio del Puig (junto a Valencia) conteniendo cerámicas del siglo XIII y comienzos del XIV, o las dos del Museo de Soller (Mallorca) llenas de cerámicas de finales del siglo XIV y principios del XV. En general, el precio de estas tinajas-contenedores estaba comprendido en el de las cerámicas a transportar dentro de ellas, pues solo en algunos documentos se especifica lo que el comprador debería pagar por ellos. En el caso de los azulejos, tenían que ir empaquetados en sacos.

Incluso la cerámica es uno de los envases más utilizados tanto para llevar piezas más pequeñas como para otro tipo de objetos, velas, vino, aceite, jabón, miel. Los recipientes más utilizados en estas ocasiones son las jarras y los cántaros. Las tinajas para vino y las de aceite solían estar recubiertas de una funda trenzada de esparto (así han continuado estando hasta fecha reciente, y aún las podemos contemplar en algunas viejas almazaras y bodegas). Tiene, además, gran importancia en arqueología, ya que por las condiciones de su propia naturaleza perdura casi inalterable a lo largo del tiempo, siendo en muchas ocasiones el único testimonio que nos queda para reconstruir el pasado.

En el Llibre del Consolat de Mar, código valenciano de legislación marítima medieval, se recogen una serie de ordenaciones, usos y prácticas marítimas y comerciales que rigieron el tráfico marítimo en gran parte del Mediterráneo hasta el siglo XVIII. En él conservamos unas ordenanzas que hacen referencia a la carga y descarga de tinajas en las naves, así como al transporte de tinajas vacías durante la Edad Media ${ }^{80}$. Sin embargo, desconocemos casi por completo cómo se efectuaría el envío terrestre de las piezas cerámicas en la frontera entre Aragón y Valencia.

\section{MATERIALES DE CONSTRUCCIÓN}

Hemos hablado de la dualidad manifiesta de la producción manufacturera del barro, en su vertiente cerámica y de elementos de construcción. Ahora abordaremos este segundo aspecto, no sin antes constatar que la industria de la construcción significó mucho para el desarrollo económico de los países de la Corona de Aragón en los siglos XIII-XVI, entre otras cuestiones porque asociaba distintos sectores artesanos en un único proceso productivo que comenzaba y acababa en un mismo lugar. Así, resultó fundamental para la reconversión de las economías urbanas, sobre todo donde se concentraba el poder y la riqueza ${ }^{81}$.

80. Libre del Consolat de Mar, Edición de G. Colón Domènech y A. García SAnz, Fundació Noguera (Textos i Documents, 2), Barcelona, 2001; reedición de la obra conjunta que ambos autores publicaron en cuatro volúmenes entre los años 1981 y 1987.

81. Véase Navarro Espinach, G., «La industria de la construcción en los países de la Corona de Aragón (siglos XIII-XVI)» ponencia presentada a la XXXVI Settimana di Studi: «L'edilizia prima della Rivoluzione Industriale. Seccoli XIII-XVIII (Prato, 26-30 aprile 2004), actas en prensa. 
Debemos señalar que tanto en Aragón como en Valencia, desde los primeros años del siglo XV se aprecia un gran incremento de la edificación a todos los niveles. Se trata de grandes y costosas obras patrocinadas por las clases económica y socialmente altas y por iniciativa de la iglesia, de la monarquía y de los organismos oficiales (municipios, diputación, etc.), lo que genera trabajo para un amplio número de artistas y trabajadores en general, incrementando con ello la circulación monetaria y la capacidad de compra de la población ${ }^{82}$.

Las obras de construcción de mayor envergadura en la Corona de Aragón, y concretamente en los dos reinos peninsulares que la formaban, fueron las catedrales, objeto de atención preferente para la historiografía. A todos los efectos, a finales de la Edad Media se mantenían cuatro sedes episcopales en Aragón (Zaragoza, Huesca, Tarazona y Albarracín) y dos en Valencia (Valencia y Segorbe). Sobre la edificación de algunas de estas seis catedrales disponemos ya de estudios específicos en los que, según el profesor G. Navarro, predomina el tratamiento descriptivo de las fuentes y de los procesos industriales, atendiendo poco a la comparación entre unas y otras, y sin abordar aspectos básicos en el análisis como el peso estratégico de la obra en el ámbito local, su impacto regional o interregional, o los ciclos de actividad de la misma en relación con la demografía y el desarrollo económico.

En el caso de Zaragoza, durante la dilatada historia de su catedral podemos identificar varias etapas de construcción desde la conquista cristiana de esta ciudad islámica en 1118, momento en el que se consagra como templo catedralicio bajo la advocación del Salvador, hasta la culminación del lento y prolongado proceso de transformación de su fábrica en el siglo Xvi bajo el mandato del arzobispo don Hernando de Aragón (1539-1575). Por lo que a nuestro tema de interés se refiere, debemos subrayar que las relaciones entre estos dos reinos se confirma una vez más en función de haberse documentado durante 1434-1435 la intervención del maestro Pere Joan en el retablo mayor de la catedral y los trabajos de unos picapedreros valencianos para extraer alabastro en la cantera de Gelsa, localidad cercana a Zaragoza.

Por su parte, en el reino de Valencia ha sido Pedro López Elum quien se ha encargado de contrastar la documentación escrita con la investigación arqueológica y la cultura material al tratar los materiales y las técnicas constructivas de los castillos valencianos durante la Edad Media ${ }^{83}$. Aspecto que demuestra el objetivo último del historiador, el cual no debe dejarse llevar por un tipo u otro de

82. Sesma, J. Á., Transformación social y revolución comercial..., citado, p. 21.

83. López Elum, P., Los castillos valencianos en la Edad Media (materiales y técnicas constructivas), 2 vols., Valencia, 2002. 
fuentes escritas, iconográficas o arqueológicas, sino que debe contrastar el mayor número posible de fuentes disponibles, creadas por intencionalidades múltiples.

Centrándonos particularmente en el tema que nos ocupa, conocemos que durante mucho tiempo los alfareros estuvieron asociados al gremio de los albañiles y de los maestros de obra. De esta manera, contribuían ampliamente en el sector de la construcción fabricando los revestimientos de las paredes, los techos, los peldaños de las escaleras y todo el pavimento de los edificios públicos y privados.

En la edificación o reparación de las obras de construcción solían participar maestros de obra y peones, además de otros ayudantes como mozos, mujeres, niños y transportistas, acompañados éstos últimos de ciertos animales de carga y arrastre. El salario de un maestro era aproximadamente el doble que el de un obrero y casi cinco veces más que el de una mujer. Asimismo y por lo que respecta a los materiales empleados, sabemos que se utilizaban vasijas de amasar, cubos y varios andamios. Por ejemplo, el alquiler de la vasija costaba 6 dineros al día, mientras que el cubo era de 3. Utilizaban, además, cribas, cántaros, capazos, cordeles, sogas y vasijas pequeñas. Aunque los materiales empleados de más alto coste fueron los ladrillos o rajolas valoradas alrededor de 480 dineros el millar, el yeso o aljez a 126 dineros el amud (= 1.943 litros), y diversos tamaños de tablones de madera y cañas.

En el caso de la azulejería, tipología cerámica que por ser revestimiento aislante, pero a su vez esencialmente ornamental, estuvo mucho más abierta a la recepción de nuevos temas al compás de los cambios de gusto. Ya en el siglo XIV se desarrolló la industria azulejera siendo las rajolas azules valencianas las que más éxito alcanzaron en esta manufactura. Al principio las piezas fueron cuadradas y hexagonales y se decoraban en azul y blanco, con clara influencia musulmana en sus dibujos hasta el triunfo del estilo gótico. De la fama de estos azulejos da idea que Pedro IV pidiera a Valencia piezas para decorar su palacio de Tortosa en 1370. En 1362 se encargaron a dos maestros de Manises pavimentos para el palacio de los papas de Aviñón. Y también los vemos en el monasterio de Poblet, en Navarra, en Illuecas, para cuyo castillo los pidió el papa Luna. Sin embargo, los mejores ejemplares son los del interior de la cúpula del convento de la Concepción Francisca de Toledo, encargados a Valencia por el rico mercader toledano Gonzalo López de la Fuente.

Los tipos de azulejos más comunes eran los cuadrados (rajoles), los rectangulares (rajoletes) y los hexagonales (alfardons), que combinaban con baldosas rojas. La ornamentación de los azulejos, al igual que la de las distintas piezas cerámicas, fue muy variada a pesar de utilizar casi exclusivamente el azul (procedente del yacimiento de Chóvar) y el blanco, aunque en el siglo XV se decoraran otros en dorado y manganeso. Además, para los alfareros de la época había dos clases de piezas doradas la obra de pinzel decorada a mano sin 
modelo previo, y la obra de contrafet en la que el maestro había hecho el dibujo previamente.

Por otro lado, dada la envergadura de estas obras se emplearon dos sistemas de producción. Uno era el de hacer los azulejos en el obrador en el que habitualmente trabajaban y enviarlos desde allí al lugar del encargo, y otro el instalarse el azulejero en la localidad para la que se solicitaban y producirlos allí.

Las «rajoletes pintades», baldosas de cerámica decoradas, aseguraron la fama de los artistas de Paterna y Manises. De hecho, en 1446, el mismo Alfonso $\mathrm{V}$ hace expedir un cargamento de «rajoletes pintades de Manises», decoradas con las armas reales, para su castillo de Nápoles; o, a finales de siglo, Alejandro VI, de los Borja, contrata a Bernardino di Betto para decorar sus dependencias y a los artistas valencianos para realizar los pavimentos, cuyas copias se reprodujeron en 1974 en la casa Borgia y en el arte contemporáneo del Vaticano, siguiendo el modelo de los originales ${ }^{84}$. También la azulejería manisera alcanzó un gran auge, en buena parte por la actividad de los duques de Gandía, que encargaron azulejos para sus palacios y para las estancias vaticanas. De Manises proceden asimismo los azulejos de muchos pavimentos de iglesias francesas e italianas (sobre todo napolitanas).

En otras ocasiones, como hemos comentado, resultaba más rentable trasladar a los alfareros para realizar in situ su trabajo que transportar los azulejos. Es lo que hizo en 1361 el Arcipreste de Morella, como apoderado del Cardenal francés Aubert Audoin, obispo de Ostia y archidiácono de Valencia, que contrató «magistri operis terre» de Manises y de Paterna para ir a Aviñón a fabricar «azulejos de diferentes colores» para decorar su palacio. De Paterna fueron Rodrigo Martínez, Martín Enríquez, Avdalá y Jucef Alquitani, entre otros cuyos nombres no se pueden leer por deterioro del documento. A todos se les pagaría el tiempo del viaje de ida y vuelta (aproximadamente diecisiete días para ir desde Valencia a Aviñón) así como el tiempo que emplearan en construir los hornos. Luego se pagaría la producción a 9 florines de oro por cada millar de azulejos. Sabemos que los alfareros pidieron además al Cardenal, dos mulas para transportar sus útiles de trabajo y los colores que necesitaban y se reservaron el derecho a realizar otros encargos en Aviñón cuando terminaran con el del Cardenal ${ }^{85}$. También el duque de Berry contrató en Poitiers azulejeros valencianos. Esta cerámica de gran renombre, como hemos tenido ocasión de comprobar, fue copiada en muchos otros lugares como Muel, Cataluña, Sevilla,

84. Véase Guiral, J., Valencia, puerto mediterráneo..., citado, p. 503.

85. Osma, G. J., Adiciones a los textos y documentos valencianos..., citado, p. 20. 
y los mejores museos nacionales y extranjeros albergan bellísimas piezas salidas de estos alfares ${ }^{86}$.

Pero sobre estos materiales de construcción no sólo fue afamado el reino de Valencia, sino también el de Aragón, donde por ejemplo vemos actuar, en 1493, en el palacio real de la Aljafería de Zaragoza, a Faraig de Gali como maestro mayor de las obras, junto a Mahoma Palacio e Ibrahim Mofferriz, moros habitantes de Zaragoza, dedicados a la construcción del alizar (friso de azulejos) y la cubierta de la sala nueva de la Aljafería por un importe de 8.000 sueldos $^{87}$. Así como unos años antes el caso de García Gonzálvez, alfarero turolense que, en 1404, aparece mencionado en relación con el envío de azulejos para las obras del palacio real de Barcelona ${ }^{88}$; o el de Lorenzo Madrid, azulejero toledano, que no sólo obró azulejería pintada en Zaragoza, sino que más tarde estuvo activo en Cataluña (Manresa y Barcelona) y Valencia, donde trabajaría, por ejemplo, para la Generalidad de Barcelona o el Colegio del Patriarca de Valencia ${ }^{89}$.

Por lo que se refiere a las tejerías que produjeron teja y regola, imprescindibles también para la construcción, fueron durante la Baja Edad Media en ocasiones de propiedad municipal, arrendándose a cambio de una cantidad concreta por un plazo determinado de tiempo, aunque no faltaron, por supuesto, las privadas. La técnica de fabricación era relativamente sencilla; así, que aunque el molde establecido para el ladrillo pudo variar según las ciudades, teniendo unas medidas fijas, en todo caso, parecen haberse regido siempre por similares criterios de proporción entre el largo y ancho de la pieza, siendo el primero prácticamente el doble del segundo, lo que facilitaba notablemente las tareas de construcción y su disposición a soga y tizón.

De esta mercancía también nos ha quedado registro documental, ya que sabemos que se importan por la aduana de Barracas un total de 100 rajolas en una única partida de entrada durante el primer ejercicio fiscal, que protagoniza el moro Hamet Aben Ferriz el día 13 de mayo de 1445; frente a las 4 docenas y un fardel que ingresan durante 1445-46, a cargo de Zayt Denabal (1446-VI-23) las primeras y de Salama Zaquen (1445-XII-16) el segundo. Cantidades insignificantes si las comparamos, por ejemplo, con los diez millares de tejas que en

86. Como son los casos de los Museos de Cerámica de Pedralbes, en Barcelona; Instituto Valencia de Don Juan, de Artes Decorativas y Arquelógico Nacional, en Madrid; The Hispanic Society of America, en Nueva York, y The Walters Art Gallery, en Baltimore. Con esto se contribuye a que se valore un patrimonio cerámico que en parte está pendiente de restauración (cerámica de aplicación arquitectónica).

87. Sobradiel. P. I., La arquitectura de la Aljafería. Estudio histórico-documental, Zaragoza, 1998.

88. M. Almagro y L. Llubiá, La cerámica de Teruel..., citado, doc. 4, p. 106.

89. San Vicente Pino, Á., Lucidario de Bellas Artes en Zaragoza: 1545-1599, Zaragoza, Real Sociedad Aragonesa de Amigos del País, 1991. 
1400 compró el síndico y procurador de la comunidad de las aldeas de Teruel, Gil Martínez Valdecebro, vecino de Torrijas, a Fernando el tejero, habitante de Castellón de Burriana (de la Plana), al precio de 450 sueldos jaqueses para la reparación y el adobo de casas y palacios de las salinas de $\operatorname{Arcos}^{90}$.

Finalmente, contamos con un dato curioso que nos sirve para ilustrar la gran movilidad geográfica y las constantes relaciones que algunos de estos artesanos mantenían entre Aragón y Valencia. Se trata de un proceso criminal acontecido en Zaragoza entre los años 1488 y 1489. El demandado fue un tal Andrés Fernández, alias el Cejijunto, de oficio tejero y rejolero, sobre el que recae acusación de bigamia, por estar casado en Zaragoza con Catalina del Frago y tener esposa viva anterior en Valencia. El caso es que hacia 1470 contrajo un primer matrimonio con una mujer «moriscada» valenciana llamada Beatriz Cardona en la localidad de Benisa, donde se hicieron las cartas nupciales y se intercambiaron los habituales juramentos; fruto del cual nacieron al menos tres hijos. Pasado el tiempo este hombre abandonó a su mujer e hijos, emprendiendo un periplo que le llevó a Castilla y Cataluña acabando en Zaragoza, donde casó con Catalina del Frago, esposa con la que vivió un tiempo hasta que ella se enteró de la existencia de la primera mujer, a la que había abandonado -según él porque era muxer moriscada, mala muxer e bellaqua, que le guiaba mal y no se queria regir por él-, robándole todo cuanto tenía, por lo que la pobre a la sazón estaba amancebada en Valencia con un trajinero. Por este motivo, Catalina pidió la anulación del matrimonio, mientras que Andrés se marchó de nuevo a Valencia, llevándose consigo pertenencias de ella. La sentencia del tribunal eclesiástico anuló el segundo matrimonio, con independencia de las responsabilidades en materia penal que fueron juzgadas por el Justicia de Aragón ${ }^{91}$.

\section{CONCLUSIONES}

A modo de colofón diremos que la cerámica fue reflejo de una de las industrias que tuvo una entidad considerable en nuestras fuentes documentales y que ha perdurado hasta la actualidad, tal y como corraboran los numerosos y siempre impactantes hallazgos arqueológicos (caso, por ejemplo, de la docena de hornos y restos cerámicos que salieron a la luz en Teruel en los recientes trabajos de descombro de unas viviendas ubicadas en la cuesta de la Merced a finales del año 2003, en cuyo estudio actualmente se sigue profundizando).

90. Archivo de la Comunidad de Teruel (Sección Mosqueruela), Secc. Hacienda, rollo 417, doc. 3893, 1 folio en pergamino, Torrijas, 1400-XI-9.

91. Archivo Diocesano de Zaragoza, Procesos Criminales, C-17/27, 47 folios, a los que acompaña un documento inserto. Véase Falcón PéRez, Ma . I., «Procesos por causas matrimoniales en Zaragoza en la Baja Edad Media y Primer Renacimiento» en Aragonia Sacra, IX (1994), pp. 209-252. 
Aunque el problema de sus orígenes plantea todavía múltiples interrogantes de difícil respuesta, es obvio que los alfareros, vagamente especializados en función de los encargos de los mercaderes, producían todo el repertorio posible de cerámicas, desde las destinadas a la construcción a las relacionadas con la alimentación e iluminación en la vivienda. En este sentido, la cerámica doméstica quedaba destinaba sobre todo a satisfacer un mercado local, directamente controlado por el comercio, y la demanda de aquellas áreas cercanas a las que bien los propios artesanos, bien los revendedores, eran capaces de alcanzar. Las áreas más alejadas eran abastecidas de cerámica de cocina y almacenaje, fundamentalmente ollas y cántaros, por otros alfares rurales. Por el contrario, la cerámica esmaltada de mesa era fundamentalmente comercializada por pequeños y medianos mercaderes, quienes empleaban para sus ventas toda la red de mercados semanales y ferias anuales a los que acudían los campesinos de las aldeas para proveerse de estos y otros productos.

Como hemos podido apreciar, la cerámica esmaltada española en general, y valenciana y aragonesa en particular, adquirió durante la Baja Edad Media una gran trascendencia. De su cuidada elaboración, que comportaba un alto nivel tecnológico, resultaba una producción cerámica donde las técnicas y motivos decorativos empleados eran llamativos por su carácter exótico y delicado. Fueron precisamente estas características las que motivaron su demanda por parte de las clases privilegiadas de regiones como Italia, Francia, Inglaterra o los Países Bajos. Por lo tanto, el objeto del presente estudio ha sido discernir en qué medida esta demanda, vehiculada por comerciantes también valencianos y aragoneses, pudo influir en la evolución formal, decorativa y en el proceso productivo de esta cerámica.

Es seguro que el solo estudio de la cerámica bajomedieval no es el mejor camino para aproximarse a la sociedad del momento, pero sí para revelar algunos aspectos de esa sociedad que suelen pasar desapercibidos. Fenómenos como la progresiva jerarquización de los modales y los utensilios empleados en la mesa por ejemplo, no están en absoluto desconectados con el proceso de fortalecimiento de los linajes de la aristocracia urbana, como tampoco lo está la composición de los ajuares domésticos y el auge de determinadas cerámicas de lujo con la estrategia de aristocratización de los mercaderes y menestrales enriquecidos a partir del siglo XIV y durante todo el siglo XV. De hecho, el estudio de la cerámica permite una aproximación, seguramente no de la forma transparente que quisiéramos, al proceso de surgimiento de comportamientos cada vez más diferenciados entre grupos sociales, la regionalización económica, política, social y cultural de los distintos estados integrantes de la corona aragonesa, pero también la integración de enclaves rurales en la organización de las redes comerciales. 


\section{Mapa de poblaciones aragonesas y valencianas cuya cerámica fue comercializada en el siglo $\mathrm{xV}$}

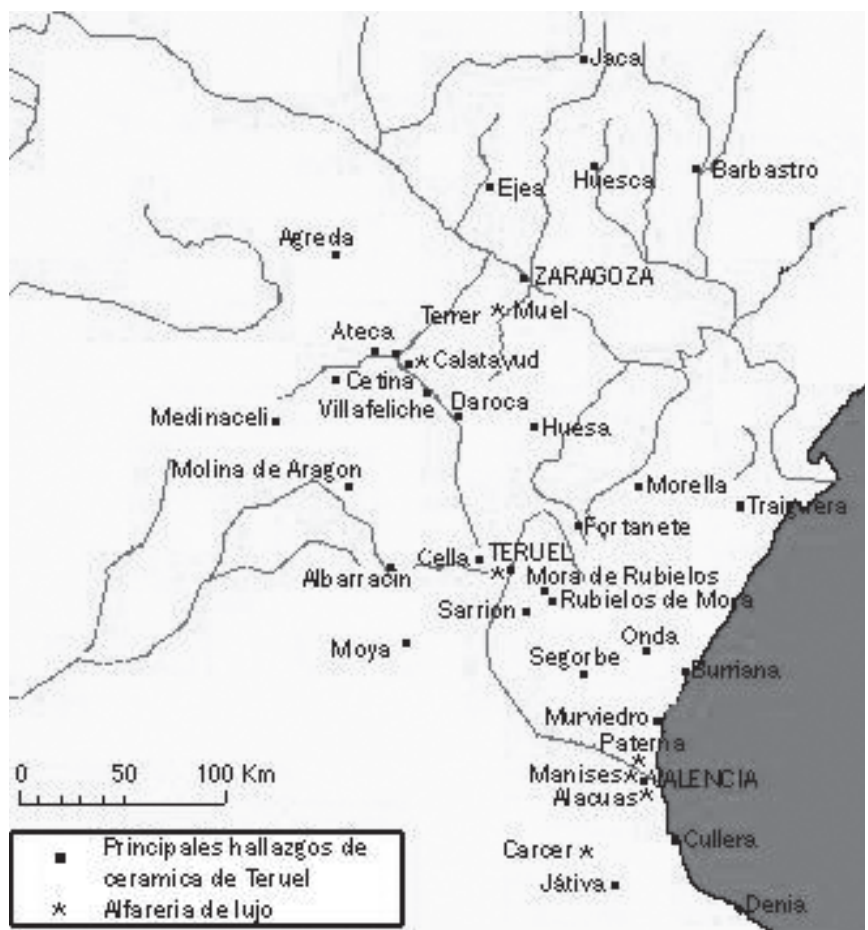

